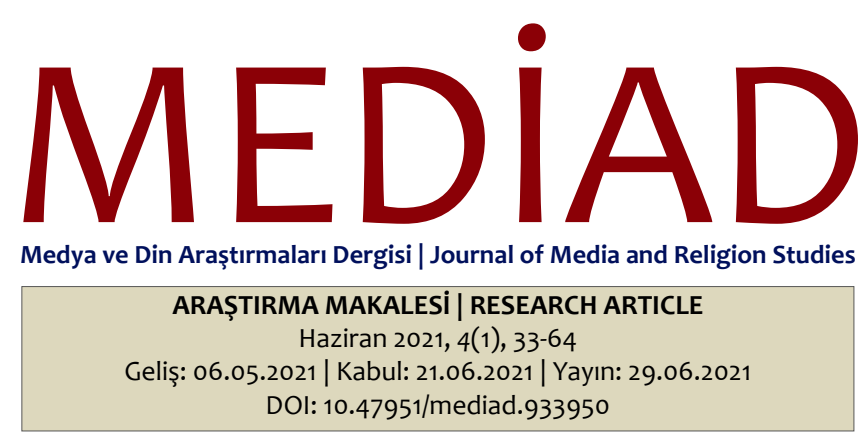

\title{
Nazi Basınında ABD'deki Yahudiler: Fliegende Blätter Mizah Dergisi Üzerine İnceleme
}

\author{
Elif Hatun KILIÇBEYLi*
}

\begin{abstract}
Öz
Uluslararası ílişkiler disiplinini oluşturan alt çalışma alanlarından biri olan Siyasi Tarih'in, sosyal bilimlerin çatısı olarak da kabul edilen Sosyoloji ile bileșiminin ortaya çıkardığı 'siyasal iletişim', toplumları bütünleştirme veya ayrıştırma özellikleri olan farklı araçlardan oluşur. Almanya'da 5 Mart 1933 yılı yapılan Genel Seçimler sonucu iktidara gelen Nasyonal Sosyalist Alman İşçi Partisi (NSDAP)'nin iktidarı elde etmesinden sonra Alman basınında Yahudi karşıtı söylemler yoğun şekilde yer bulmaya başlamıştır Özellikle Lustige Blätter, Kladderadatsch ve Fliegende Blätter gibi mizah dergilerinde Yahudiler sert biçimde eleştirilmiştir. Diğer yandan bu mizah dergileri içerisinde Fliegende Blätter'de ABD'deki Yahudi diasporası ağır şekilde eleștiriye maruz kalmıștır. Calıșmada Fliegende Blätter'deki Yahudi diasporasını konu alan karikatürler üzerinden NSDAP iktidarı döneminde Alman basınında ABD'deki Yahudi diasporasının ne şekilde sunulduğu ortaya konulmaya çalıșıımıștır. Bu aşamada çalıșma kapsamında Fliegende Blätter'in Yahudi diasporasını konu alan dergi kapakları göstergebilim yöntemi kullanılarak incelenmiştir. Calışmanın sonucu olarak Yahudi diasporasının ABD yönetimini ve kamuoyunu etkisi altına aldığına ve ABD'nin Yahudilerin kontrolü altında Almanya'ya karşı savaştığına yönelik algıların karikatürler üzerinden oluşturulmaya çalışıldığı ortaya çıkarılmıştır.
\end{abstract}

Anahtar Kelimeler: Ayrımcılık, Yahudi Diasporası, Basın, Antisemitizm, ABD, NSDP

\section{Jews in the US in the Nazi Press: Review on the Fliegende Blätter Humor Magazine}

\begin{abstract}
'Political communication', caused by the composition of political history, one of the sub-fields of study that make up the discipline of international relations, with Sociology, the roof of social sciences, consists of different tools that have the characteristics of integrating or separating societies. After the National Socialist German Workers'Party (NSDAP), which came to power as a result of the general elections held in Germany on March 5, 1933, gained power, anti-semitic rhetoric began to find an intense place in the German press. Jews were harshly criticized, especially in humor magazines such as Lustige Blätter, Kladderadatsch and Fliegende Blätter. On the other hand, the Jewish diaspora in the USA was heavily criticized in Fliegende Blätter among these humor magazines. In the study, it was tried to reveal how the Jewish diaspora in the USA was presented in the German press during the NSDAP rule over the cartoons about the Jewish diaspora in Fliegende Blätter. At this stage, the magazine covers of Fliegende Blätter on Jewish diaspora were examined using the semiotics method. It was revealed that the perceptions that the Jewish diaspora influenced the US administration and public opinion and that the USA fought against Germany under the control of the Jews were tried to be made through cartoons as a result of the study.
\end{abstract}

Keywords: Dissemination, Jewish Diaspora, Press, Antisemitism, USA, NSDP

ATIF: Kılıçbeyli, E. H. (2021). Nazi basınında ABD'deki Yahudiler: Fliegende Blätter mizah dergisi üzerine inceleme. Medya ve Din Araştırmaları Dergisi (MEDiAD), 4(1), s. 33-64.

* Doç. Dr., Adana Alparslan Türkeş Bilim ve Teknoloji Üniversitesi, e-mail: elifhatuno01@gmail.com | orcid.org/000o0001-8263-2009 


\section{Giriş}

Nasyonal Sosyalist Alman İşçi Partisi (NSDAP) lideri Adolf Hitler, 30 Ocak 1933 tarihinde Almanya'da başbakan olarak göreve başlamıştır (Bessel, 2004). Bu tarihten itibaren NSDAP'liler, yaygın bilinen ismiyle Naziler, Almanya'da siyasal ve sosyal hayata egemen olmaya başlamıştır. 2 Ağustos 1934 tarihinde cumhurbaşkanı Paul von Hindenburg'un ölümüyle birlikte de Hitler, Führer (lider) unvanılla hem cumhurbaşkanlığı hem de başbakanlık görevlerini üstlenerek ülkede mutlak kontrol elde etmeyi başarmıştır. Nazilerin, Almanya'da yegâne güç olması ülkenin Nazi Almanya'sı olarak anılmasına ve ülkede kendi düşünce ve ideolojilerini hâkim kılmaya yönelik yoğun bir propaganda gerçekleştirmesine neden olmuştur. Diğer yandan Nazi propagandası, Alman toplumunda Yahudilere yönelik düşman inşasına yönelmiş ve Yahudileri Alman toplumu ve insanlık için büyük bir tehdit olarak yansıtmıştır. Almanya'daki Yahudi diasporasının, Alman halkını ekonomik yönden sömürüye maruz bıraktığı ileri sürülmüştür. Antisemitist Nazi propagandası, Almanya'daki Yahudi diasporasının dışında ABD'deki Yahudi diasporasını da hedef almış ve Yahudilerin ABD yönetimini kontrol altına aldığını iddia etmiştir. Özellikle mizah dergilerinde ABD başkanı Franklin D. Roosevelt'in Yahudilerin kontrolü altına girdiğine yönelik iddialar, mizahi bir dille kitlelere aktarılmıştır. Bu süreçte ABD'deki Yahudi diasporasını hedef alan mizah dergilerinden biri de Fliegende Blätter olmuştur.

Yahudi diasporasını inceleyen çok sayıda uluslararası çalışma bulunmaktadır (Goldschmidt, 2000), (Aviv ve Shneer, 2005), (Safran, 2005), (Edrei ve Mendels, 2007), (Sheffer G. , 2005), (Ehrlich , 2009), (Bar-Kochva, 2010), (Stein, 2011). Bu çalışmalar içerisinde (Tcherikover, 1963), Roma döneminde Mısır'daki Yahudi diasporasını; Wink (Wink, 1987), Hindistan'daki Yahudi diasporasını; (Markowitz, 1995), Rusya'daki Yahudi diasporasını; (Shanes, 1998), milliyetçilik bağlamında Yahudi diasporasını; (Roshwald, 1998), yirminci yüzyılda Avrupa Yahudi diasporası ve Siyonizm'i; (Vieira, 2001), Latin Amerika'daki Yahudi diasporasını; Vital (Vital, 1994), (Sheffer, 2002), (Dieckhoff, 2017) ; Yahudi diasporası ve İsrail'i; (Khanin, 2002), Rus Yahudi diasporasını; (Collins-Kreiner ve Olsen, 2004), turizm pazarı boyutunda Yahudi diasporasını; (DellaPergola, Rebhun ve Tolts, 2005), küresel bağlamda çağdaş Yahudi diasporasını; (Hagel ve Peretz, 2005), Soğuk Savaş sırasında Yahudi diaspora politikasını; (Mendelsohn, 2007), on dokuzuncu yüzyılın ortalarında İngilizce konuşan Yahudi diasporasının ortaya çıkışını; (Ray, 2008), Yahudi diasporasına yönelik yaklaşımları; (Cohen, 2009), Yahudi diasporasının sosyal göstergelerini; (Evans, 2009), transatlantik denizcilik ve Yahudi diasporasını; (Levantovskaya, 2012), Rusça konuşan Yahudi diasporasını; (Zelekha, Sharabi ve Bar-Efrat, 2012), Yahudi diasporasının İsrail’in dış ticareti üzerindeki etkisini; (Lederhendler , 2014), Doğu Avrupa Yahudi diasporasını; (Elo ve Vemuri, 2016, s. 179-193), Buhara Yahudi diasporasını; Elo ve Volovelsky (Elo ve Volovelsky, 2017, s. 244-269), (Elo, Taube ve Volovelsky, 2019, s. 95-106), Yahudi diasporası girişimcilerini; (Porat, 2018), Yahudi diasporası ve Avustralya'daki İsraillileri ve (Rajak, 2018, s. 146162), antik Yunan-Roma'daki Yahudi diasporasını incelemiştir. Yahudi diasporasıyla ilgili akademik literatür incelendiğinde farklı ülke ve konularda Yahudi diasporasının ele alındığı ortaya çıkmaktadır.

Yahudi diasporasını, Amerikan Yahudi diasporası özelinde inceleyen akademik çalışmalar da bulunmaktadır (Lazerwitz, Winter, Dashefsky, \& Tabory, 1998); (DellaPergola S. , 1980); (Lazerwitz, Winter, Dashefsky, \& Tabory, 1998); (Fejgin, 1995); (Moore, 2009); (Heilman, 2006); (Beinart, 2010); (Kosmin ve Keysar, 2013) (Bauer, 2017). Bu çalışmalarda ise; (Duker, 1950), (Liebman, 1965), (Schwartz, 2007), (Krasner, 2013), Amerikan Yahudi yaşamını; (Ganin, 1977), Amerikan Yahudi siyasi gücünün sınırlarını; (Himmelfarb, 1980), (Strauss, 2011), (Fishman, 1997), (Toll, 1997), (Prell, 2000), (Rubin-Dorsky, 2001), (Butler-Smith, 2009), (Power, 2012), (Hartman, 2016), Amerikan Yahudi kimliğini; (Singerman, 1984), Amerikan Yahudi basınını; (Dinnerstein, 1987), antisemitizm ve Amerikan Yahudiliğini; (Levine, 1993) Amerikan Yahudiliği ve sporu; (Fishman, 1995), Amerikan Yahudi toplumunda feminizmi; (Sarna, 1998b), 
(Sheramy, 2003), (Jacobs, 2005), (Krasner, 2012), Amerikan Yahudi eğitimini; (Kauvar, 1993), (Zipperstien, 1997), (Sarna, 1998b), (Katz, 2015), Amerikan Yahudi kültürünü; (Urofsky, 1981), (Cohen, 1999), Amerikan Yahudi liderliğini; (Baron, 1950), (Marcus, 1958), (Feingold, 1982), (Feingold, 1983), (Sarna, 1990), (Robinson, 1994), (Kaufman, 2015), (Michels, 2000), (Alexander, 2006), (Hyman, 2003), (Shapiro, 2005), (Dauber, 2006), (Finkelstein, 2010), (Kahn, 2014), Amerikan Yahudi tarihini; (Chiswick ve Huang, 2008), Amerikalı Yahudi erkeklerin kazançlarını; (Moore, 2009), Amerikan Yahudi kimlik politikasını; (Fishman, 2015), Amerikan Yahudi yaşamında cinsiyeti; (Loeffler, 2015), Amerikan Yahudi siyasetini; (Waxman, 2018), Amerikan Yahudilerinin İsrail üzerindeki çatışmasını ele almıştır.

Çalışmada Fliegende Blätter mizah dergisi özelinde Nazilerin ABD'deki Yahudi diasporasına yönelik gerçekleştirdiği propaganda faaliyetlerine ışık tutulmaya çalışıımıştır. Bu aşamada Nazi propagandasının ABD'deki Yahudi diasporasına karşı hangi görsel ve yazılı mesajlar verdiğinin, Yahudileri nasıl sunduğunun ve Yahudilerle ilgili hangi propaganda mitlerini inșa etmeye çalıștığının ortaya konulması amaçlanmıştır. Böylece çalışma kapsamında “Nazi propagandasında ABD'deki Yahudi diasporası ne şekilde sunulmaktadır?" sorusunun yanıtlanması hedeflenmiştir. Çalışmada elde edilen bulgular, ABD'deki Yahudi diasporasına yönelik Nazi propagandası hakkında bilgi vermesi ve mizahın propaganda amaçlı kullanımına ışık tutması bakımından önem taşımaktadır.

\section{Nazilerin Yahudi Karşıtı Söylemlerine Genel Bakış}

Alman toplumunda, Birinci Dünya Savaşı'nın bitiși ve Almanya yenilgisi konusunda farklı spekülasyonlar ve şüpheler yaratılmıştı. Bu çalışmalar çoğunlukla Alman milliyetçileri tarafından yaratılmıştı. Birinci Dünya Savaşı'nda Almanya'nın yenilgisini ve Versailles Avrupası'nın yaratıcısı komünistler, plütokratlar ve doğal bir müttefik olarak liberaller idi (Stojanović, 2015, s. 95). Komünistlerin, plütokratların ve liberallerin kesişim alanında Yahudiler vardı. Masonlar ise hem Yahudi hem de liberallerin bir uzantısı olarak algilanıyordu.

Yahudilerin, Almanya'da ekonomik olarak Germen-ırkı üzerinden zenginleștiği ve Alman halkını ekonomik yönden sömürdüğüne yönelik algılar oluşturulmuştur. Ekonominin dışında da Yahudilerin, siyasetten sanata pek çok alanda Almanya'ya hakim olduğu düşüncesi kitlelere empoze edilmiştir. Ayrıca Yahudilerin dünya egemenliği düşüncesine sahip olduğuna ve bu egemenliği gerçekleştirmek için çalıştıklarına yönelik algılar meydana getirilmiştir. Diğer yandan Birinci Dünya Savaşı'nda Almanya'nın yenilgisinden de Yahudiler sorumlu tutulmuştur (Voigtlander ve Voth, 2012, s. 1339).

Nazilerin, Yahudi karşıtı gerçekleştirdikleri faaliyetlerin temelinde benimsedikleri Nazizm ideolojisi yatmaktadır. Nazizm ideolojisi, antikomünist ve antikapitalist olmasının yanında aynı zamanda antisemitist bir özellik taşımaktadır. Nazizm, Yahudileri gerek Alman halkı gerekse insanlık için önemli bir tehdit olarak ön plana çıkarmaktadır. İngiliz siyasi tarihçisi T. Mason'ın Nazi siyasetinin önceliği hakkındaki içgörüleriyle yakından bağlantılı olan, Nazi politikasını kaçınılmaz olarak kendini yok etme eğiliminde olarak tanımlamasıdır. Bu görüş ilk bakışta bir ikilem oluşturur, çünkü Nazi rejimi askeri, siyasi ve bürokratik gücün daha büyük hedeflerine hizmet etmesi için rasyonel uygulamasıyla bilinir. Bu bilmecenin çözümü tam olarak, yaşam boyu faşizm endişesi altında olan seçkin sanayiciler ve siyaset arasındaki karmaşık ilişkide yatmaktadır. T. Mason, 1938'e gelindiğinde Nazi rejiminin aşılmaz gibi görünen bir krizle karşı karşıya olduğunu ve en belirgin manifesta iyonlarından biri olan ciddi bir işgücü kıtlığıyla karşı karşıya olduğunu iddia etmiştir (Horn, 1997). Burada bir yanda Yahudi karşıtlığı diğer yanda Nazi olmayan işçi sınıfının ayrımcılığı sonunda üretkenliğin düşmesi bir gerekçe olarak kabul edilebilir. Nazi sosyal politikasının modernitenin 1930'larda yaşadığı finansal kriz yıllarından dolayı travma yaşayan bireylere ve ailelere göreceli bir istikrar sağlayabildiği de diğer bir etkendir. 
Bu aşamada Nazi politikalarında Nazi olmayan ve Germen-ırk'ından olmayanlara karşı propagandalar geliştirilmiştir.

Naziler, Almanya'da iktidara geldikten sonra Yahudi karşıtı çeşitli faaliyetlere girişmiştir. Nazilerin, Almanya'da medyayı kontrol altına almasından sonra Alman basınında antisemitist söylemler güç kazanmıştır. Bu aşamada Lustige Blätter, Kladderadatsch ve Fliegende Blätter gibi mizah dergilerinde Yahudiler eleştiriye maruz kalmıştır. Özellikle Julius Streicher tarafından çıkarılan Der Stürmer gazetesinde Yahudilere yönelik nefret söylemine varan olumsuz ifadelere yer verilmiştir. Gazetenin mottosu ise Die Juden sind unser Unglück! (Yahudiler bizim talihsizliğimiz!) olmuştur. Ayrıca Streicher tarafından Der Giftpilz (Zehirli Mantar) adıyla çocuklara yönelik antisemitist hikaye kitabı yayınlanmış ve hikaye kitabında Yahudilere yönelik olumsuz algıların meydana gelmesine neden olacak açıklamalara yer verilmiștir. Nazilerin baskı tehdidi, halkın rejimin ekonomik ve uluslararası başarıları hakkındaki algıları ve Yahudi karşıtı propagandası nedeniyle Alman halkında antisemitizm zaman içerisinde artmıştır (Smith, 1998). Ayrıca 15 Eylül 1935 tarihinde Nürnberg Yasaları (Nürnber Gesetze) ortaya çıkarılmış ve yasa kapsamında Almanya'daki Yahudi diasporasının belirli hakları ellerinden alınmıștır. Diğer yandan Almanya'da 9-10 Kasım 1938 tarihinde Kristal Gece (Kristallnacht) olarak bilinen Yahudilere yönelik şiddet olayı gerçekleştirilmiş, olaydan sonra Yahudi diasporasının Almanya'da varlığını sürdürmesi daha da güç hale gelmiştir.

i̇kinci Dünya Savaşı sırasında Yahudilere yönelik olumsuz propaganda sürdürülmüş ve Nazi propagandası savaşın sorumlusu olarak Yahudileri ön plana çıkarmıştır. Nazi propagandası savaş sırasında Almanya'nın dışında Alman ordularının işgali altında bulunan topraklarda da antisemitist propaganda faaliyetlerine yönelmiştir. Naziler, tehdit olarak ön plana çıkardıkları Komünizm ideolojisi ile de Yahudileri ilişkilendirmiştir. Özellikle Nazi Almanya'sında halkı aydınlatma ve propaganda bakanı olarak görev alan Dr. Joseph Goebbels, Komünizm ve Yahudiler arasındaki bağ olduğunu iddia etmiş ve sert şekilde eleştirmiştir (Goebbels, 2016). Naziler, antisemitist mitler inşa ederek Yahudilerin ortak düşman olduğuna yönelik algı meydana getirmeye çaIışmıştır. Diğer yandan savaş sırasında Nazi Almanya'sında Jud Süß (1940), Die Rothschilds (1940) ve Der ewige Jude (1940) gibi çeșitli antisemitist filmler yayınlanmıştır. Bu filmlerde Yahudilere eleştiriye maruz bırakılmıştır. Ayrıca hazırlanan propaganda posterlerinde de Yahudilerin Müttefik Devletleri'ni etkisi altına aldığına yönelik mesajlar verilmiş ve Almanya'nın dışında Alman ordularının işgali altındaki ülkelerde Yahudi karşıtı güçlü bir kamuoyu oluşturulmaya çalışıımıştır.

\section{Nazilerin ABD'deki Yahudi Diasporasına Yönelik Propagandası}

Naziler, yalnızca Almanya'da yaşayan Yahudilere değil farklı ülkelerde yaşayan Yahudilere yönelik de olumsuz propaganda faaliyetine yönelmiştir. Özellikle ABD'deki Yahudi diasporası, doğrudan Nazi propagandasının hedefinde yer almıștır. Naziler, ABD'deki Yahudi diasporasının önemli bir güç haline geldiğini ve ülke yönetiminde söz sahibi olduğunu iddia etmiştir. Bu aşamada Nazi propagandası dönemin ABD başkanı Franklin D. Roosevelt üzerinden Yahudi diasporasını hedef almıştır. ABD'deki Yahudi diasporasının Roosevelt'i etkisi altına aldığı ve Roosevelt'in aldığı kararlarda ABD'deki Yahudi diasporasının etkili olduğu ileri sürülmüştür. İkinci Dünya Savaşı sırasında Nazi Almanya'sının ABD'ye savaş ilan etmesiyle Nazi propagandası, ABD'deki Yahudi diasporasını savaşın sorumlusu olarak ön plana çıkarmıştır. Nazi Almanya'sı, 1 Eylül 1939 tarihinde Polonya'ya saldırarak İkinci Dünya Savaşı'nı başlattığında, ABD, İngiltere ve Fransa'nın aksine savaşın dışında kalmayı tercih etmiştir. Alman orduları, Sovyetler Birliği'ne karşı istila planı olan Barbarossa Harekâtı'nı 22 Haziran 1941 tarihinde başlattığında (McNab, 2015)ve Avrupa kıtasının önemli bir bölümünde denetim kurmayı başardığında da ABD, tarafsızlığını sürdürmüştür. Buna karşılık 7 Aralık 1941 tarihinde Japonya'nın Pearl Harbor limanındaki ABD donanmasına saldırmasından dört gün sonra Hitler, ABD'ye savaş ilan etmiştir. Nazi Almanya'sının ABD'ye savaş ilanının Alman kamuoyunda destek bulması ve savaşın meşrulaştııılması sürecinde Nazi propagandası ABD'deki Yahudi diasporasına yönelik sert söylemlere yönelmiştir. Bu aşamada Nazi 
propagandası, Nazi Almanya'sının ABD'ye yönelik savaşının ABD halkına karşı değil, sözde ABD'yi kontrolü altında tutan Yahudilere karşı olduğunu ileri sürmüştür.

Naziler, ABD'deki Yahudi diasporasına yönelik propagandasını yalnızca Almanya'da değil işgal altındaki topraklarda da gerçekleştirmiştir. Bunun en çarpıcı örneklerinden biri Nazilerin iktidar olduğu dönem işgal edilen Sırbistan'da gerçekleştirilen Büyük Masonluk Karşıtı Sergi'dir. Nazi döneminde işgal edilen Sırbistan'da 22 Ekim 1941 - 19 Ocak 1942 tarihleri arasında düzenlenen Büyük Masonluk Karşıtı Sergi, Nazilerin Yahudi diasporasına karşı gerçekleştirdikleri önemli propaganda faaliyetlerinden biri olmuştur. Almanya tarafından işgal edilen Sırbistan'da, Milan Nedic hükümeti doğrudan Nazi yönetimiyle işbirliğine girmiştir. Sırbistan hükümeti, Hitler'in 'Yeni Avrupa' düşüncesini kabul ederek ' Yahudi-Mason-Bolşevik’ komplosunu sona erdirme niyetindeydi (Nenezić, 1987). Sırbistan 1941-1944 yılları Nazilerle işbirliği çerçevesinde ideolojik ve aynı zamanda diğer tüm sosyal gruplara karşı Germen-ırkı'nın düşmanları olarak etiketlenen Yahudilere karşı yoğun ve acımasız bir baskıyı uyguladı. Masonlar hiyerarşide belirgin bir yere sahipti ve Yahudilerin bir koluydu (Jovanovich, 1972).

Yugoslavya Krallığı'nda yer alan Sırbistan'da Temmuz 1940'tan itibaren, Yugoslavya'nın Mihver devletlere katılması için baskı yapan Nazi Almanyası'nın siyasi etkisi ile anti-masonik propaganda dalgası'da başladı. Dr. Lazar Prokić ve Stevan Kluić de bu kampanyanın önde gelenleri olarak, Nazi işgali sırasında Belgrad'da Bir Anti-Masonik sergi düzenleme çalışmasını destekleyerek katıldılar. Sergi, eski büyük Mason Locası olan "Yugoslavya" binasında yapıldı ve Sırp işbirlikçilerin propaganda faaliyetleri arasında en büyük etkinliklerinden biriydi. Serginin açıış tarihi 22 Ekim 1941'den kapanış günü 19 Ocak 1942'ye dek resmi kaynaklara göre yaklaşık 80.000 kişi ziyaret etti. Belgrad sergisinin içeriği, işgal altındaki Paris ve Brüksel'de düzenlenen sergiler gibi ve aynı anda özgür masonları, Yahudileri ve komünistleri hedef alan Mason karşıtı görsellerden oluşmuştu. 1941 yılının sonbaharında ve kışında Sırbistan'daki direnişçilerle işbirlikçi güçlerin yoğun mücadelesi, Anti-Masonik serginin propaganda rolünü güçlendirdi. Sergi, işbirlikçi basında yayınlanan yüzlerce şiddetli anti-semitik ve anti-komünist makaleye ilham verdi. Tarihsel kaynaklar ve karşılaştırmalı analizler, Belgrad Anti-Masonik sergisinin planlayıcısı ve hazırlayanlar ile mali destek sağlayanların Germen-ırk'ından Alman hayırseverlerinin olduğunu; organizasyon ve propaganda çalışmalarının ise savaştan çok önce Nazizmin destekçisi olan ve Alman gizli servisleriyle işbirliği yapan prokić gibi radikal işbirlikçilere bırakıldığını göstermiştir (Stojanović, 2015, s. 122).

Sergide, Nazizm ideolojinin antisemitist söylemleri ön plana çıkmış ve diğer yandan Yahudi diasporasının etkinliği vurgulanmıştır. Örneğin sergide yer alan The New York Times başılıkı bir posterde, ABD'deki Yahudi diasporasının, ABD basının 97\%'sini kontrol ettiği iddia edilmiştir (Museum, 1993). 


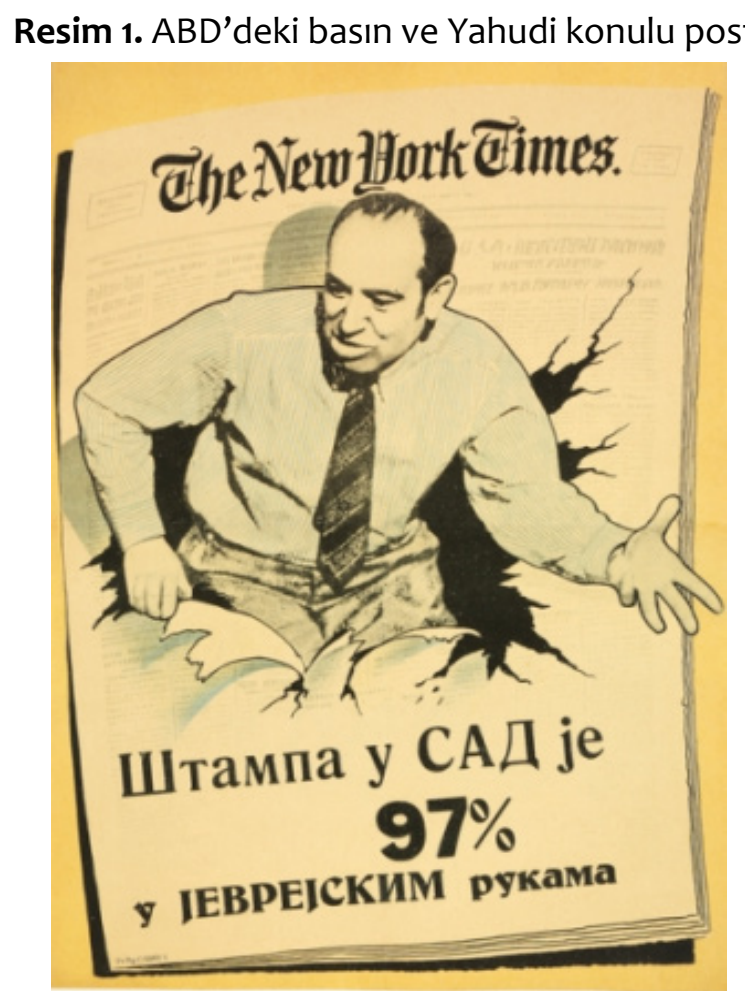

\section{Kaynak: (Sulzberger, 1941)}

27 Mayıs - 2 Haziran 1942 tarihleri arasında Almanya'nın Münih kentinde yayınlanan Yahudi karşıtı Nazi propaganda posterinde önde gelen altı Yahudi'nin resimlerine yer verilmiștir (Resim 2): Bernard Baruch (ABD Başkanları Woodrow Wilson ve Franklin D. Roosevelt 'in danışmanı); Felix Frankfurter (ABD Başkanları Woodrow Wilson ve Franklin D. Roosevelt'in danışmanı); Maksim Masimovich Litvinov (doğum adı Meir Henoch Mojszewicz Wallach-Finkelstein; silahsızlanma ve Birinci Dünya savaşından önce Nazi Almanyası'na karşı Batılı devletlerle ortak bir ittifak oluşturulmasını savunan Sovyet diplomat); Leslie Hore-Belisha (1937-40 yılları arasında Parlamento üyesi ve Britanya Savaş Bakanı); Walther Rathenau (1914-15'te Alman Savaş Bakanlığı'nda Savaş Hammaddeleri Dairesi başkanı, 1921'de Yeniden Yapılanma Bakanı ve 1922'de dışişleri bakanı olarak görev yapan sanayici ve devlet adamı) ve Kurt Eisner (Almanya'nın Birinci Dünya Savaşı'na katılmasına karşı çıkan ve 1918'de 'Özgür Bavyera' sosyalist devrimin ilk devlet adamı)dır. Nazi propagandası, sözde yalnızca Almanya'daki Yahudi diasporasının değil ABD'deki Yahudi diasporasının da Alman halkı için tehdit oluşturduğuna kitleleri inandırmaya çalışmıştır. Bu şekilde ünlü Yahudiler ön plana çıkarılarak, sözde Almanya'ya karşı alınan kararlarda bazı Yahudilerin rolü olduğuna yönelik algı oluşturulmasına zemin hazırlanmıştır. 
Resim 2. Ünlü Yahudiler konulu poster ${ }^{2}$

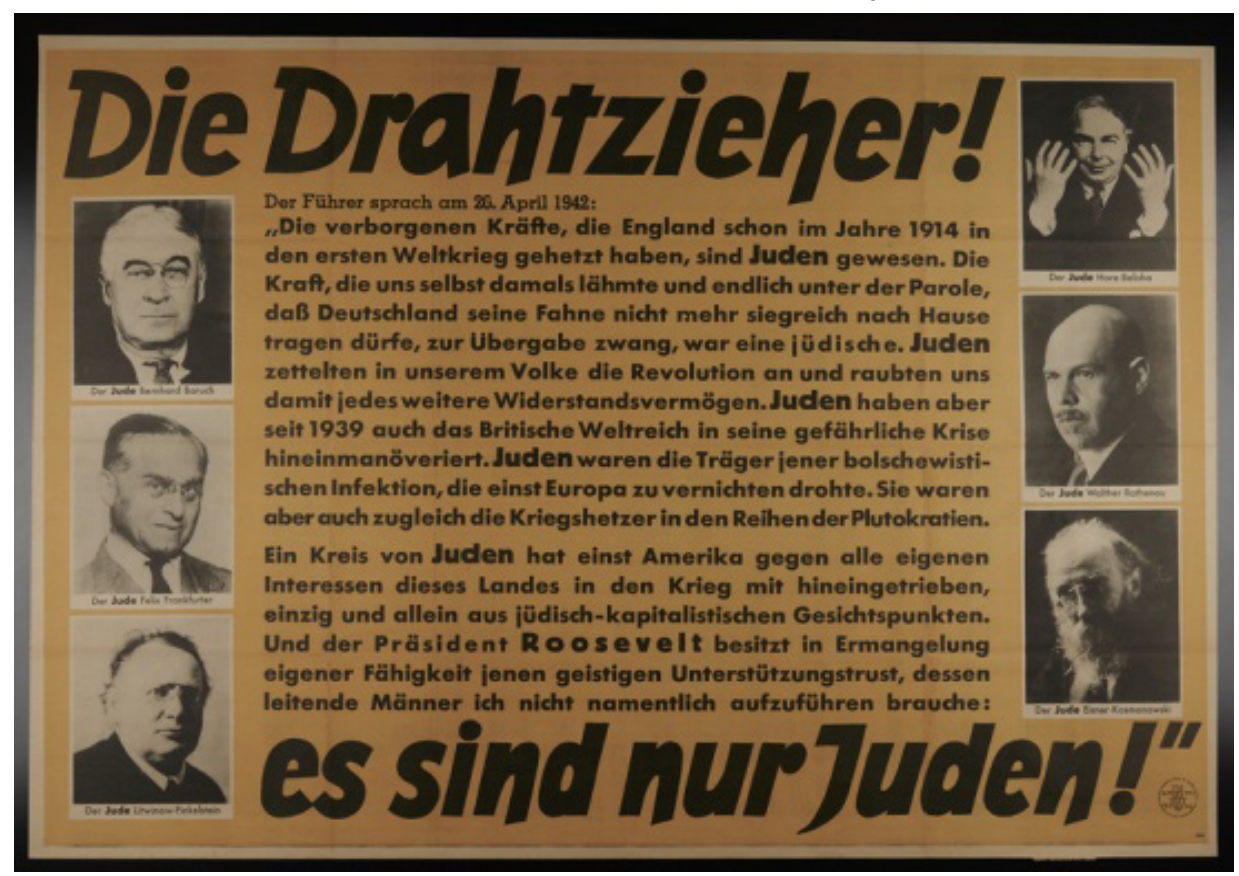

Kaynak: (Collection, 1942)

\section{Metodoloji}

Çalışmada Nazi propagandasının, ABD'deki Yahudi diasporasına karşı söylemlerinin Fliegende Blätter mizah dergisi özelinde incelenmesinin birkaç nedeni bulunmaktadır. Bu nedenler derginin: antisemitist propaganda faaliyetlerine yönelmesi, Roosevelt'in Yahudi diasporasının etkisi altında kaldığı iddiasında bulunması ve ABD'de Yahudi diasporasını doğrudan hedef alması șeklinde sıralanabilmektedir. Çalışma kapsamında Fliegende Blätter'in 1942 yılı boyunca yayınlanan sayıları üzerinden Nazi propagandasının ABD'deki Yahudi diasporası karşıtı söylemleri incelenmiştir. Çalışmada derginin 1942 yılındaki sayılarının incelenmesinin temel nedeni, ABD’ni İkinci Dünya Savaşı'na 1941 yılının Aralık ayında dahil olması ve Nazi Almanya'sının ABD'ye 11 Aralık 1941 tarihinde savaş ilan etmesidir. Bu tarihten Nazi Almanya'sının kayıtsız şartız savaştan ayrılacağı tarihe kadar, her iki ülke savaş halinde kalmıştır. Bu açıdan 1942 yılı içerisinde Nazilerin ABD'deki Yahudi diasporasına yönelik propagandaya odaklanılacağı düşünülmüş ve derginin 1942 yılındaki sayıları örneklem olarak belirlenmiştir. Derginin 1942 tarihi içerisinde toplam 53 sayısı yayınlanmış ve çalışmada 53 sayının 53 dergi kapağı incelenmiştir. 53 dergi kapağı içerisinde 12 dergi kapağının doğrudan ABD'deki Yahudi diasporasını hedef aldığı ortaya çıkmış, bu nedenle çalışma 12 dergi kapağı özelinde gerçekleştirilmiştir.

Çalışmada nitel araştırma yöntemlerinden biri olan göstergebilimden yararlanılmıştır. Örneklem olarak belirlenen 12 dergi kapağındaki temsillerin ve ideolojik söylemlerin ortaya konulabilmesi için Fransız dilbilimci Roland Barthes'ın (19151980) göstergebilim modelinden yararlanılmıștır. Göstergebilim, göstergelerin anlamlandırılmasını amaçlamaktadır. Ferdinand de Saussure ve Charles Sanders Peirce'ın dilbilimi çalışmalarıyla ortaya çıkan göstergebilim (Sığırcı, 2016, s. 29), Barthes'ın katkılarıyla da önemli bir gelişme sergilemiştir. Barthes'ın göstergebilim modelinde, gösteren, gösterilen, düz anlam, yan anlam ve mit kavramları ön plana çıkmaktadır. Gösteren bir kavramın herkes tarafından kabul edilen evrensel anlamını; gösterilen ise bir kavramın herkes tarafından kabul gören ilk anlamının dışındaki ikinci anlamını ifade etmektedir. Gösteren ve gösterilen kavramları, İsviçreli dilbilimci Saussure tarafından ortaya konulmuş, Barthes tarafından da kullanılmıştır. Barthes her iki kavrama ek olarak düz anlam ve yan anlam kavramlarını göster- 
gebilime kazandırmıştır. Düz anlam, insanların belirli bir göstergeler dizgesine yönelik ilk algılarını; yan anlam ise göstergeler dizgesi içerisinde inşa edilmek istenen ikinci anlamı ifade etmektedir. Diğer bir deyişle düz anlam, doğrudan görünen anlamı; yan anlam ise gizli kalan ve ilk aşamada doğrudan fark edilemeyen anlamı açıklamaktadır. Yan anlamda ortaya konulan anlam, kültürden kültüre farklı olabilmektedir (Barthes, 2014, s. 25).

Barthes, düz anlam ve yan anlam kavramlarının dışında mit kavramına da vurgu yapmıştır. Barthes'a göre mitler, egemen güçlerin ideolojik söylemlerinnin topluma benimsetilmesi amacıyla inşa edilen düşünceleri açılamaktadır. Mitler, egemen güçlerin denetimindeki kitle iletişim araçları yoluyla kitlelere benimsetilmeye çalışılmakta ve egemen güçlerin ideolojik söylemleri üzerinden neyin doğru neyin yanlış, kimin dost kimin düşman olacağına karar verilmesi amaçlanmaktadır. Egemen güçlerin toplumdaki dilinin analizinde de göstergebilim ön plana çıkmaktadır (Barthes, 2015, s. 57). Göstergebilim çözümlemelerinde mitin dışında metafor, metonimi ve simge kavramları da ön plana çıkabilmektedir. Metafor, bir kavramın başka bir kavramı tanımlaması; metonimi de aralarında belirli bir ilişki bulunan unsurlardan birinin diğerini ifade etmesi için kullanılmasıdır. Simge ise bir unsurun, bir simge, bir sayı, bir işaret vb. ile temsil edilmesidir. Çalışmada örneklem olarak belirlenen 12 dergi kapağı, Barthes'ın göstergebilim anlayışı ışığında düz anlam, yan anlam, metafor, metonimi, simge ve mit kavramları üzerinden ele alınmıştır.

\section{Bulgular ve Yorum}

Çalışmanın bu kısmında vatandaş, kukla, at, yönetici, hükümdar, heykel, Amerika, bebek, savaş, araba, oyuncak ve film konulu 12 dergi kapağı göstergebilimsel açıdan incelenmiştir.

\subsection{Vatandaş Konulu Dergi Kapağı}

Vatandaş konulu dergi kapağı, Josef Mauder tarafından hazırlanmıştır. Düz anlam boyutunda incelendiğinde dergi kapağında bir erkeğin, üstünde USA (ABD) yazan rozet taşıyan diğer bir erkeğe iki elinin avuç içlerini tuttuğu aktarılmaktadır. Her iki erkeğin bir sahnede olduğu ve onları diğer kişilerin izlediği yansıtılmaktadır. Sahnenin bir köşesinde Kasse (Kasa) yazan bir kürsüde bir kadın ve kadının yanında da iri burun ve dudaklı bir erkeğin olduğu resmedilmektedir. Diğer yandan sahnedeki duvarda dolar ve altıgen yıldız işaretleri ile üstünde orak ve çekiç yer alan bir yıldız bulunmaktadır. Ayrıca sahne duvarında üstlerinde King Georg ve Stalin yazan iki ayrı erkek resmi yer almaktadır. Dergi kapağında Ich brauche den USA-Bürger nur noch etwas tiefer einzuschläfern... (Sadece ABD vatandaşını biraz daha derin uyutmam gerekiyor...) yazısı bulunmaktadır. 
Resim 3. Vatandaş konulu dergi kapağı

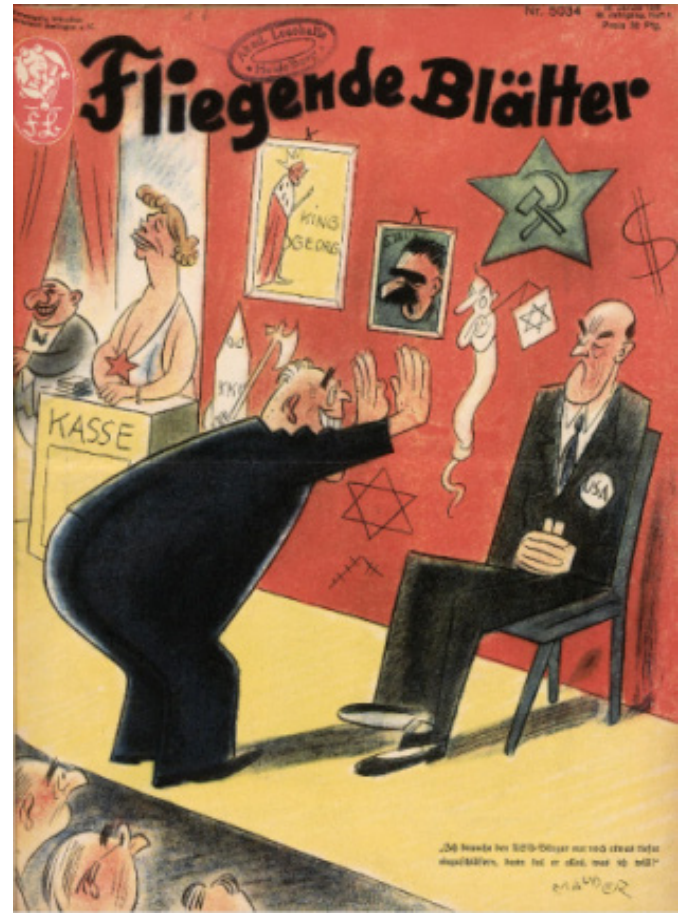

Kaynak: (Blätter, Heidelberg historic literature - digitized, 1942)

Dergi kapağı yan anlam üzerinden incelendiğinde Yahudi diasporasının ABD kamuoyunu etkilediği algıının oluşturulmaya çalışıldığı ortaya çıkmaktadır. USA rozeti taşıyan erkek, ABD halkının metonimi olarak kullanılmıştır. Dergi kapağındaki görsel ve yazılı kodlardan USA rozeti taşıyan erkeği elleriyle yönlendirmeye çalışan kişinin de Yahudileri temsil ettiği anlaşılmaktadır. Sahnedeki altıgen yıldız, Yahudiliği; orak ve çekiç Komünizm ideolojisini ve dolar işareti Kapitalizm'i simgelemektedir. Bu şekilde sözde ABD kamuoyunu etkilemeye çalışan Yahudi diasporasının Komünizm ve Kapitalizm'le iç içe olduğu mesajı verilmeye çalışılmaktadır. Dergi kapağında Yahudi diasporası, egemenlik metaforu olarak sunulmuştur. Böylece "Yahudi diasporası, ABD kamuoyunu şekillendirir" miti inşa edilmeye çalışılmaktadır. İnşa edilen propaganda miti üzerinden ABD'de kamuoyunun oluşumunda Yahudilerin doğrudan etkili olduğu mesajı verilmektedir. Bu süreçte $A B D$ halkının savaşa destek vermesi aşamasında da Yahudilerin etkili olduğu algısı oluşmakta, bu da Yahudi diasporasına yönelik olumsuz bir Alman kamuoyunun meydana gelmesine yol açmaktadır.

Tablo 1. Vatandaş konulu dergi kapağı

\begin{tabular}{|c|c|}
\hline Düz Anlam & Sahnede bulanan iki erkek \\
\hline Yan Anlam & Yahudi diasporasının ABD kamuoyunu etkilediği iddiası \\
\hline Metafor & Yahudi diasporası, egemenlik metaforu olarak sunulmuştur \\
\hline Metonimi & USA rozeti taşıyan erkek, ABD halkının metonimi olarak kullanılmıştır \\
\hline Simge & $\begin{array}{l}\text { Altıgen yıldız, Yahudiliği; orak ve çekiç Komünizm ideolojisini ve dolar } \\
\text { işareti Kapitalizm’i simgelemektedir }\end{array}$ \\
\hline Mit & $\begin{array}{c}\text { "Yahudi diasporası, ABD kamuoyunu şekillendirir" miti inşa edilmeye } \\
\text { çalışılmaktadır }\end{array}$ \\
\hline
\end{tabular}




\subsection{Kukla Konulu Dergi Kapağı}

Kukla konulu dergi kapağı, Max Bauer tarafından hazırlanmıștır. Düz anlam açısından ele alındığında dergi kapağında başının üstünde altıgen yıldız olan, saçı bukleli bir erkeğin, sırasıyla Roosevelt, Churchill ve Stalin'e benzetilmeye çalışılan üç kuklayı tutuğu resmedilmektedir. Dergi kapağında Das Weltjudentum: "Nun habe ich sie zu gleicher Zeit auftreten lassen, und trotzdem ist der Stalin schon kaputt." (Dünya Yahudiliği: "SSimdi aynı anda performans sergilemelerine izin veriyorum, ancak Stalin çoktan bozulmuş.") yazısı bulunmaktadır.

Resim 4. Kukla konulu dergi kapağı

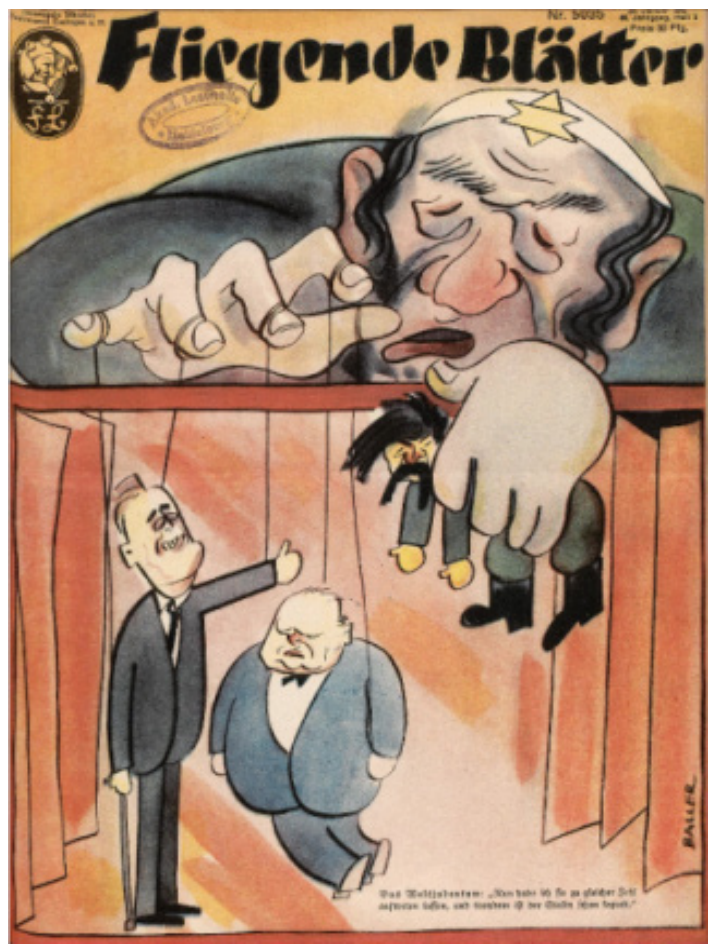

Kaynak: (YerTutucu2)

Dergi kapağı yan anlam boyutunda ele alındığında Yahudi diasporasının Müttefik Devletleri'ni yönettiği algısının oluşturulmaya çalışıldığı anlaşılmaktadır. Altıgen yıldız, Yahudiliği simgelemektedir. Başında altıgen yıldız bulunan erkek de Yahudilerin metonimi olarak kullanılmıştır. Roosevelt, Churchill ve Stalin'e benzetilmeye çalışılan üç kukla da sırasıyla üç büyük Müttefik devleti, $A B D$, İngiltere ve Sovyetler Birliğ̈i'nin yönetimlerini temsil etmektedir. Stalin'e benzetilmeye çalışılan kuklanın bozulduğu söylemiyle Alman ordusunun 22 Haziran 1941 tarihinde başlattığı Sovyetler Birliği'nin istila planına vurgu yapıldığı belirtilebilmektedir. Dergi kapağının yayınlandığı tarihte Sovyetler Birliği'nin topraklarının bir kısmı Nazi Almanya'sı işgali altında bulunmaktadır. Dergi kapağında Yahudileri temsil eden kişinin, Müttefik Devletleri'nin liderlerine benzetilmeye çalışılan kuklaları yönetmesiyle, Yahudilerin üç büyük Müttefik devletini yönettiği mesajı verilmeye çalışılmaktadır. Bu açıdan Yahudi diasporası, güç metaforu olarak kullanılmıştır. Böylece "ABD yönetimi, Yahudi diasporasının kontrolü altındadır" miti inşa edilmeye çalışılmaktadır. İnşa edilen propaganda miti üzerinden savaşın sorumlusu olarak Müttefik Devletleri'nin halkları değil doğrudan Yahudi diasporası suçlanmaktadır. Bu şekilde Alman kamuoyunda Nazi Almanya'sına karşı savaşın Müttefik Devletleri'nin halkları tarafından değil sözde Müttefik Devletleri'ni ele geçiren Yahudi diasporası tarafından sürdürüldüğüne yönelik algı oluşturulmaya çalışılmaktadır. 
Tablo 2. Kukla konulu dergi kapağı

\begin{tabular}{|c|c|}
\hline Düz Anlam & Kuklaları tutan bir erkek \\
\hline Yan Anlam & Yahudi diasporasının Müttefik Devletleri’ni yönettiği iddiası \\
\hline Metafor & Yahudi diasporası, güç metaforu olarak kullanılmıştır \\
\hline Metonimi & Başında altıgen yıldız bulunan erkek, Yahudilerin metonimi olarak kullanılmıştır \\
\hline Simge & Altıgen yıldız, Yahudiliği simgelemektedir \\
\hline Mit & “ABD yönetimi, Yahudi diasporasının kontrolü altındadır” miti inşa edilmeye çalışılmaktadır \\
\hline
\end{tabular}

\subsection{At Konulu Dergi Kapağı}

At konulu dergi kapağı, Josef Mauder tarafından hazırlanmıştır. Düz anlam boyutunda incelendiğinde dergi kapağında Roosevelt'e benzetilmeye çalışılan bir erkeğin üstünde altıgen yıldız bulunan bir ata bindiği resmedilmektedir. Erkeğin sağ kolunda $A B D$ bayrağı, sağ göğsünde de üzerinde orak ve çekiç görseli yer alan bir yıldız bulunmaktadır. Erkek, sol eliyle şapka, sağ eliyle de baston tutmaktadır. Dergi kapağında Sei nur schön brav, mein Demokratenroß, dann kriegst du von mir alles, was ich will! (Sadece uslu ol benim demokrat atım, o zaman benden istediğim her şeyi alacaksın!) yazısı bulunmaktadır.

Resim 5. At konulu dergi kapağı

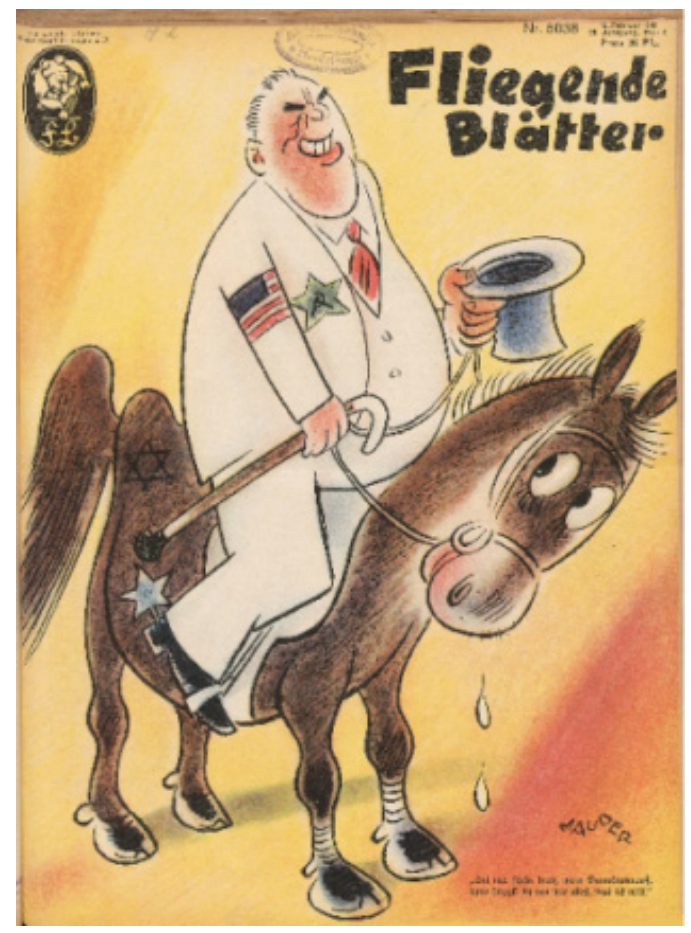

Kaynak: (Blätter, Heidelberg historic literature - digitized, 1942)

Dergi kapağı yan anlam üzerinden incelendiğinde Yahudi diasporasının ABD yönetimine yön verdiği algısının oluşturmaya çalışıldığı ortaya çıkmaktadır. Baston, Roosevelt'in metonimi olarak kullanılmıştır. Dergi kapağında yer alan baston, Roosevelt'in bedensel engeline vurgu yapmaktadır. Bedensel engeli nedeniyle, Roosevelt, kimi karikatürlerde bastonla veya koltuk değneğiyle resmedilmektedir. Altıgen yıldız, Yahudiliği; ABD bayrağı, ABD halkını ve orak ve çekiç Komünizm ideolojisini simgelemektedir. Dergi kapağında yer alan atın üzerinde altıgen yıldızın bulunması ve Roosevelt temsilinin atın üzerine binmesi, Roosevelt'in Yahudi diasporasından destek aldığı algısını oluşturmaktadır. Bu aşamada Yahudi diasporası, yardım metaforu olarak kullanılmıştır. Böylece " $A B D$ yönetimi, Yahudi diasporası lehine hareket 
etmektedir” miti inşa edilmeye çalışılmaktadır. İnşa edilen propaganda miti üzerinden yine Roosevelt ve Yahudi diasporası arasındaki sözde ilişkiye vurgu yapılması amaçlanmıştır.

Tablo 3. At konulu dergi kapağı

\begin{tabular}{|c|c|}
\hline Düz Anlam & Ata binen bir adam \\
\hline Yan Anlam & Yahudi diasporasının, ABD yönetimine yön verdiği iddiası \\
\hline Metafor & Yahudi diasporası, yardım metaforu olarak kullanılmıştır \\
\hline Metonimi & Baston, Roosevelt'in metonimi olarak kullanılmıştır \\
\hline Simge & $\begin{array}{c}\text { Altıgen yıldız, Yahudiliği; ABD bayrağı, ABD halkını ve orak } \\
\text { ve çekiç Komünizm ideolojisini simgelemektedir }\end{array}$ \\
\hline Mit & $\begin{array}{c}\text { "ABD yönetimi, Yahudi diasporası lehine hareket etmekte- } \\
\text { dir" miti inşa edilmeye çalışılmaktadır }\end{array}$ \\
\hline
\end{tabular}

\subsection{Yönetici Konulu Dergi Kapağı}

Yönetici konulu dergi kapağı, Max Bauer tarafından hazırlanmıştır. Düz anlam açısından ele alındığında dergi kapağında Roosevelt'e benzetilmeye çalışılan bir erkeğin çevresinde mutlu şekilde yansıtılan iri burunlu ve dudaklı erkeklerin olduğu resmedilmektedir. Dergi kapağında Der Streiter für die Christenheit im Kreise seiner Manager (Yöneticileri arasında Hıristiyanlığın şampiyonu) yazısı bulunmaktadır.

Resim 6. Yönetici konulu dergi kapağı

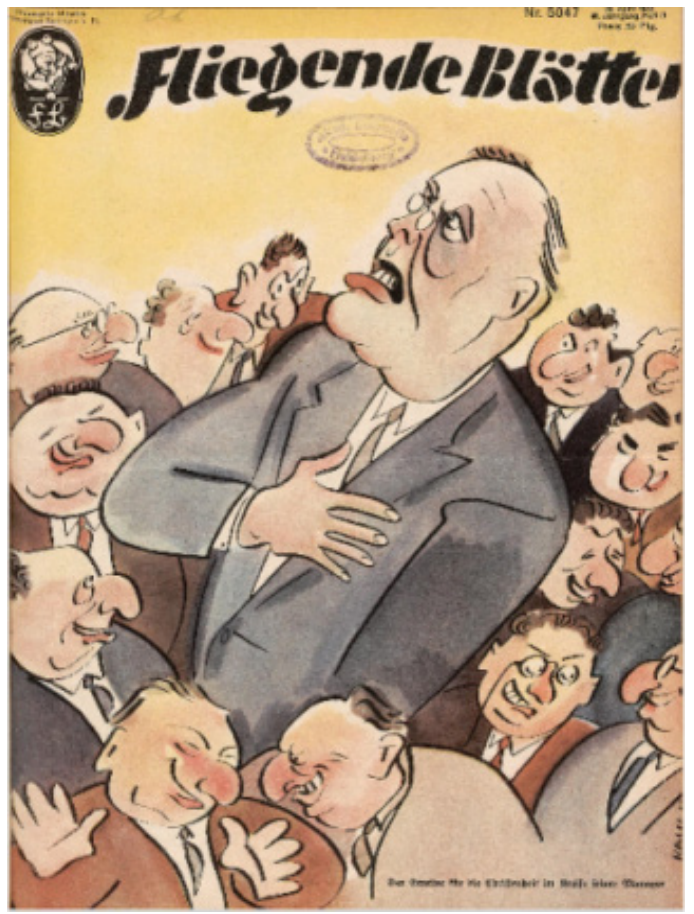

Kaynak: (Blätter, Heidelberg historic literature - digitized, 1942)

Dergi kapağı yan anlam boyutunda ele alındığında Roosevelt'in çevresinin Yahudilerle çevrildiği algısının oluşturulmaya çalışıldığı anlaşılmaktadır. İri dudak ve iri burunlar Yahudilerin metonimi olarak kullanılmıștır. Yahudilerin iri burunlu ve dudaklı olarak resmedilmesi, Nazi propaganda karikatürlerinde karşılaşılabilen bir durumdur. Nazilerin Yahudi karşıtı karikatürlerinde Yahudilere atıf yapıldığı̆ı algııı olușturabilmek için Yahudiler iri burunlu ve dudaklı sunulabilmektedir. Dergi kapağında Roosevelt temsili, ABD yönetimini simgelemektedir. Roosevelt'in çevresinde bulunan Yahudi temsilleriyle "ABD yönetimi, Yahudi diasporasının kontrolü altına girmiştir" miti inşa 
edilmeye çalışılmaktadır. Bu açıdan dergi kapağında Yahudi diasporası, kontrol metaforu olarak kullanılmıştır. Nazi propagandası dergi kapağı üzerinden ABD yönetiminin Yahudilerin denetimi altına girdiğine yönelik algıyı oluşturması, savaşın sorumlu olarak Yahudilerin ön plana çıkmasına neden olabilmektedir. Diğer yandan dergi kapağındaki yazılı kodla ülke yönetiminde Yahudiliğin egemen hale geldiğine yönelik algı meydana gelebilmektedir.

Tablo 4. Yönetici konulu dergi kapağı

\begin{tabular}{|c|c|}
\hline Düz Anlam & Çevresi insanlarla sarılmış bir erkek \\
\hline Yan Anlam & Roosevelt'in çevresinin Yahudilerle çevrili olduğu iddiası \\
\hline Metafor & Yahudi diasporası, kontrol metaforu olarak kullanılmıştır \\
\hline Metonimi & $\begin{array}{c}\text { İri dudak ve iri burunlar Yahudilerin metonimi olarak } \\
\text { kullanılmıştır }\end{array}$ \\
\hline Simge & Roosevelt, ABD yönetimini simgelemektedir \\
\hline Mit & $\begin{array}{c}\text { "ABD yönetimi, Yahudi diasporasının kontrolü altına girmiş- } \\
\text { tir” miti inşa edilmeye çalışılmaktadır }\end{array}$ \\
\hline
\end{tabular}

\subsection{Hükümdar Konulu Dergi Kapağı}

Hükümdar konulu dergi kapağı, Josef Mauder tarafından hazırlanmıştır. Düz anlam boyutunda incelendiğinde dergi kapağında dört erkek görseline yer verilmektedir. Erkeklerden biri, Roosevelt'e benzetilmeye çalışmıştır. Diğer üç erkek ise iri burunlu ve dudaklı olarak resmedilmiştir. Dergi kapağında iri burunlu ve dudaklı erkeklerin sırasıyla Roosevelt'e benzetilen erkeği sakal tıraşı ettiği, tırnaklarına bakım yaptığı ve üstünü temizlediği aktarılmaktadır. Roosevelt'e benzetilmeye çalışılan erkeğin elinde de üstünde New York Sowjet Times yazısı ve orak ve çekiç görseli bulunan bir gazete tuttuğu resmedilmektedir. Dergi kapağında Mer ham schon de höchsten Herrschaften eingeseift, König und Kaiser, aber bei Ihnen machts ä besonderes Vergnügen! (Zaten en yüksek hükümdarları, Kral ve İmparatoru köpürtmüş durumdayız, ama sizinle birlikte bu özel bir zevk!) yazısı bulunmaktadır.

Resim 7. Hükümdar konulu dergi kapağı

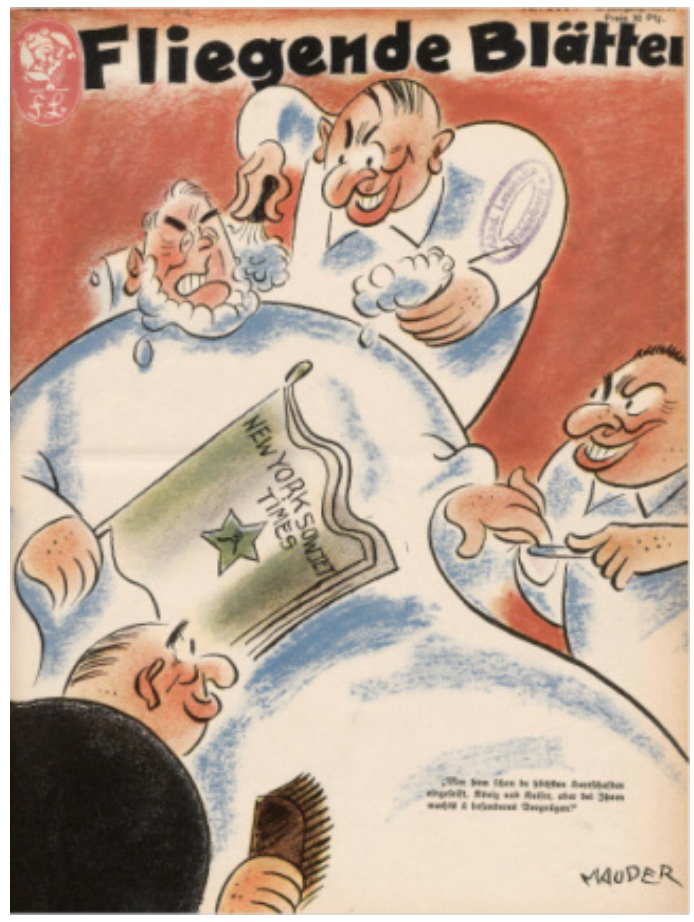

Kaynak: (Blätter, Heidelberg historic literature - digitized, 1942) 
Dergi kapağı yan anlam üzerinden incelendiğinde bir önceki dergi kapağında olduğu gibi Roosevelt'in çevresinin Yahudilerle çevrili olduğu algısının meydana getirilmeye çalısııldığı ortaya çıkmaktadır. İri dudak ve iri burunlar Yahudilerin metonimi olarak kullanılmıştır. Yahudi temsillerinin Roosevelt temsilini sakal tırașı etmesi, tırnak bakımı yapması ve üstünü fırçalaması, Yahudi diasporasının Roosevelt için çalıştığı düşüncesini meydana getirmektedir. Bu aşamada Yahudi diasporası, kontrol metaforu olarak kullanılmıştır. Roosevelt temsilinin elindeki gazetenin üzerindeki orak ve çekiç Komünizm ideolojisini simgelemektedir. Diğer yandan gazetenin üzerindeki yazı da ABD medyasında Komünizm'in etkili olduğuna yönelik algı oluşturmaktadır. Tüm bu süreçte dergi kapağında "ABD yönetimi, Yahudi diasporası etkisinde kalmaktadır” miti inşa edilmeye çalışılmaktadır. Böylece yine $A B D$ ve Nazi Almanya'sı arasındaki savaşın sorumlusu olarak Yahudilerin ön plana çıkarıldığı ileri sürülebilmektedir.

Tablo 5. Hükümdar konulu dergi kapağı

\begin{tabular}{|c|c|}
\hline Düz Anlam & Sakal tıraşı olan bir adam ve ona hizmet eden üç kişi \\
\hline Yan Anlam & Roosevelt'in çevresinin Yahudilerle çevrili olduğu iddiası \\
\hline Metafor & Yahudi diasporası, kontrol metaforu olarak kullanılmıştır \\
\hline Metonimi & $\begin{array}{l}\text { İri dudak ve iri burunlar Yahudilerin metonimi olarak } \\
\text { kullanılmıştır }\end{array}$ \\
\hline Simge & Orak ve çekiç Komünizm ideolojisini simgelemektedir \\
\hline Mit & $\begin{array}{c}\text { “ABD yönetimi, Yahudi diasporasının etkisi altında kalmak- } \\
\text { tadır” miti inşa edilmeye çalışılmaktadır }\end{array}$ \\
\hline
\end{tabular}

\subsection{Heykel Konulu Dergi Kapağı}

Heykel konulu dergi kapağı, Rolf Peter Bauer tarafından hazırlanmıştır. Düz anlam açısından ele alındığında dergi kapağında Özgürlük Heykeli'ne benzetilmeye çalışılan bir heykelin sol eliyle Roosevelt'e benzetilmeye çalışılan erkeğe işaret ettiği resmedilmektedir. Roosevelt'e benzetilmeye çalışılan erkeğin üstünde ABD bayrağı bulunan bir masada olduğu ve üzerinde altıgen yıldız ve dolar işareti bulunan bir koltukta oturduğu aktarılmaktadır. Heykel, sinirli olarak yansıtılmakta ve heykelin yanında valiz resmedilmektedir. Dergi kapağının arka planında binalar aktarılmakta, binaların arkasında silahlı ve gözlerinin çevresi maskeli bir erkekle ile iri burunlu diğer bir erkek yansıtılmaktadır. Dergi kapağının sağ tarafındaysa bir elin uzatıldığı ve uzatılan ele paralar düștüğü aktarılmaktadır. Dergi kapağında Ich bitte um meine Ausreisebewilligung, Herr Präsident. Was soll denn ich noch in Ihrem Lande? (Çıkış iznimi istiyorum, Sayın Başkan. Senin ülkende ne yapmalıyım ki?) yazısı bulunmaktadır. 
Resim 8. Heykel konulu dergi kapağı

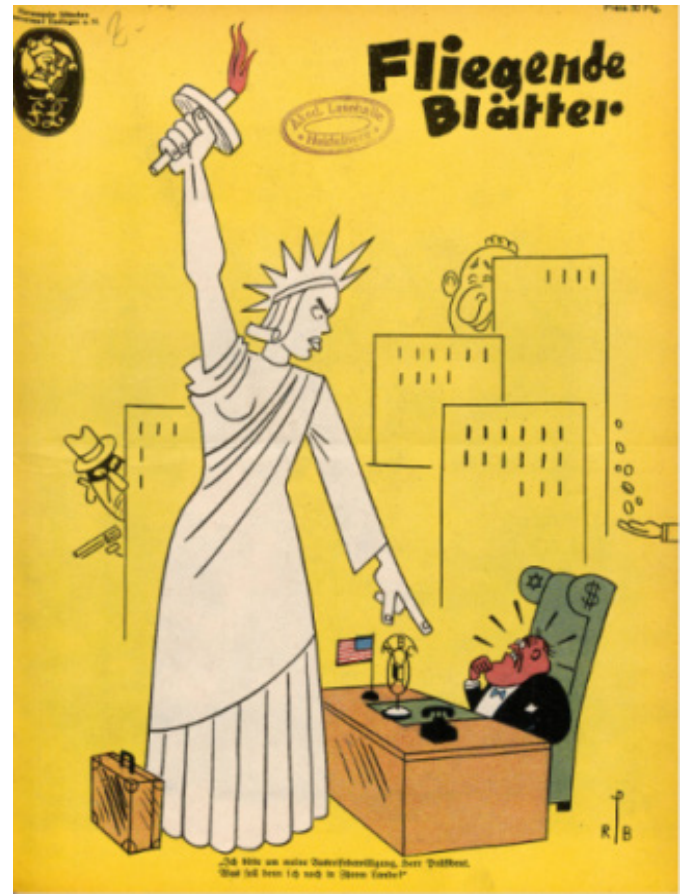

Kaynak: (Blätter, Heidelberg historic literature - digitized, 1942)

Dergi kapağı yan anlam boyutunda ele alındığında Roosevelt'in bağımsız hareket edemediğine yönelik algının oluşturulmaya çalışıldığı anlaşılmaktadır. Özgürlük heykeli, özgürlüğü; $A B D$ bayrağı, $A B D$ halkını; dolar, Kapitalizm'i ve altıgen yıldız, Yahudiliği simgelemektedir. Silahlı adam ABD'deki yasa dışı güçlerin, iri burunlu adam ise Yahudilerin metonimi olarak kullanılmıştır. Özgürlük heykeli temsilinin, Roosevelt temsilini hedef almasıyla $A B D$ yönetiminin özgürlükten uzaklaştığı ve Yahudilerin eline geçtiği iddia edilmektedir. Bu aşamada dergi kapağının arka planında yer alan ele paraların düşmesiyle rüşvetin temsil edildiğine yönelik algı meydana gelebilmektedir. Diğer yandan silahlı ve gözlerinin çevresi maskeli erkekse, yasa dışı güçleri çağrıştırabilmektedir. Görsel ve yazılı kodlar bir bütün olarak okunduğunda dergi kapağında ABD'nin Yahudilerin denetimine girdiği ve yasa dışı güçlere karşı hareket edemediği algısı oluşabilmektedir. Dergi kapağında Yahudi diasporası, kontrol metaforu olarak kullanılmıştır. Bu şekilde "ABD yönetimi, Yahudi diasporası tarafından yönlendirilmektedir" miti inşa edilmeye çalışılmaktadır. Inşa edilen propaganda mitiyle yine ABD yönetiminin Yahudi diasporasının etkisi altına girdiği mesajı verilmektedir.

Tablo 6. Heykel konulu dergi kapağı

\begin{tabular}{|c|c|}
\hline Düz Anlam & Heykel ve onun işaret ettiği bir adam \\
\hline Yan Anlam & Roosevelt'i bağımsız hareket edemediği iddiası \\
\hline Metafor & Yahudi diasporası, kontrol metaforu olarak kullanılmıştır \\
\hline Metonimi & $\begin{array}{c}\text { Silahlı adam ABD'deki yasa dışı güçlerin, iri burunlu adam ise Ya- } \\
\text { hudilerin metonimi olarak kullanılmıştır }\end{array}$ \\
\hline Simge & $\begin{array}{c}\text { Özgürlük heykeli, özgürlüğü; ABD bayrağı, ABD halkını; dolar, } \\
\text { Kapitalizm'i ve altıgen yıldız, Yahudiliği simgelemektedir }\end{array}$ \\
\hline Mit & $\begin{array}{c}\text { “ABD yönetimi, Yahudi diasporası tarafından yönlendirilmekte- } \\
\text { dir” miti inşa edilmeye çalışılmaktadır }\end{array}$ \\
\hline
\end{tabular}




\subsection{Amerika Konulu Dergi Kapağı}

Amerika konulu dergi kapağı, Josef Mauder tarafından hazırlanmıștır. Düz anlam boyutunda incelendiğinde dergi kapağında üç erkeğe yer verilmektedir. Erkeklerden biri Roosevelt'e, bir diğeri de Churchill'e benzetilmeye çalışılmıştır. Roosevelt'e benzetilmeye çalışılan erkeğin sağ eliyle Churchill'e benzetilmeye çalışılan erkeğin başını tuttuğu, sol eliyle ise kıyafetinde üstünde orak ve çekiç bulunan bir yıldız taşıyan, iri burunlu ve dudaklı bir erkeğin omzunu tuttuğu resmedilmektedir. Dergi kapağında Das große, freie Amerika weiß, wofür es kämpft (Büyük, özgür Amerika ne için savaştığını bilir) yazısı bulunmaktadır.

Resim 9. Amerika konulu dergi kapağı

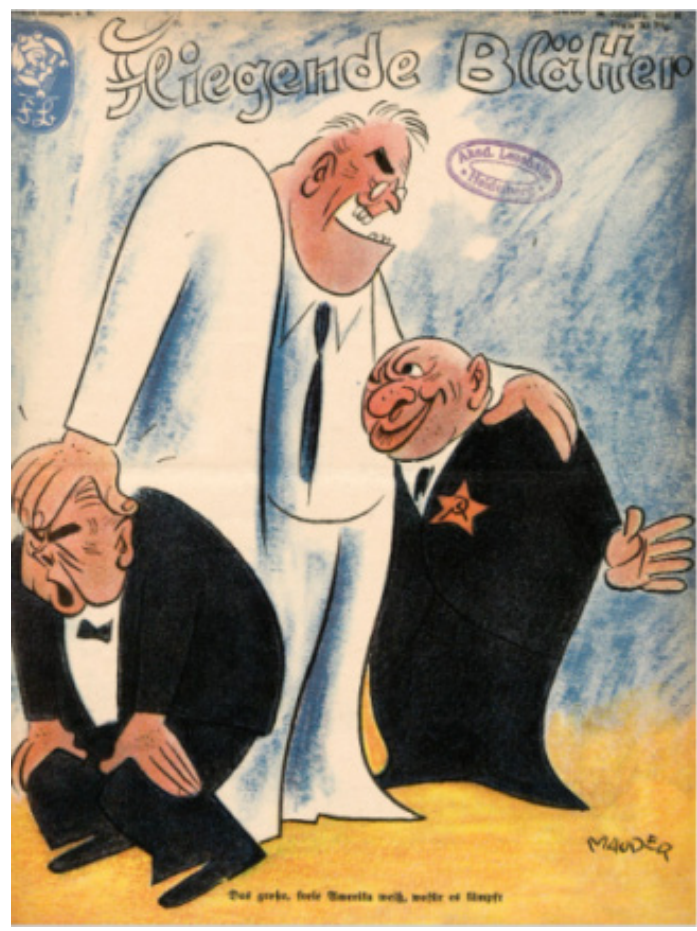

Kaynak: (Blätter, Heidelberg historic literature - digitized, 1942)

Dergi kapağı yan anlam üzerinden incelendiğinde Roosevelt'in Yahudilerin etkisi altında kaldığı algısının oluşturulduğu ortaya çıkmaktadır. Roosevelt, ABD'yi; Churchill, Ingiltere'yi ve orak ve çekiç, Komünizm ideolojisini simgelemektedir. İri dudak ve iri burunlu erkek, Yahudilerin metonimi olarak kullanılmıştır. Yahudi temsilinin kıyafetindeki yıldızın üzerinde orak ve çekiç görselinin bulunmasıyla Yahudiler ve Komünizm arasındaki bir ilişki meydana getirilmektedir. Roosevelt temsilinin elini, Yahudi temsilinin omzuna koyması, ABD yönetiminin Yahudi diasporasına destek verdiği algısını oluşturmaktadır. Roosevelt temsilinin diğer elini Churchill temsilinin kafasına koymasıyla da $A B D$ yönetiminin önceliğinin Yahudiler olduğuna yönelik düşünce meydana gelebilmektedir. Diğer yandan dergi kapağındaki görsel ve yazılı kodlar bir bütün olarak incelendiğinde ise ABD'nin Nazi Almanya'sına karşı savaşma nedeninin Yahudiler olduğu algısı oluşmaktadır. Dergi kapağında Yahudi diasporası, bağlılık metaforu olarak kullanılmıştır. Bu aşamada "Yahudi diasporası, ABD yönetimi üzerinde etki oluşturmaktadır" miti inşa edilmeye çalışılmaktadır. İnşa edilen propaganda miti üzerinden ABD'nin Nazi Almanya'sıyla savaşı sürdürmesinin nedeni olarak Yahudiler ön plana çıkarılmaktadır. 
Tablo 7. Amerika konulu dergi kapağı

\begin{tabular}{|c|c|}
\hline Düz Anlam & $\begin{array}{c}\text { Bir adam ve birini başında diğerini de omzundan tuttuğu diğer iki } \\
\text { adam }\end{array}$ \\
\hline Yan Anlam & Roosevelt'in Yahudilerin etkisi altında kaldığı iddiası \\
\hline Metafor & Yahudi diasporası, bağlılık metaforu olarak kullanılmıştır \\
\hline Metonimi & İri dudak ve iri burunlu erkek, Yahudilerin metonimi olarak kulla- \\
nılmıştır
\end{tabular}

\subsection{Bebek Konulu Dergi Kapağı}

Bebek konulu dergi kapağı, Josef Mauder tarafından hazırlanmıştır. Düz anlam açısından ele alındığında dergi kapağında Roosevelt'e benzetilmeye çalışılan bir erkeğin, üstünde WC yazan bebek kıyafetleri içerinde ve İngiliz asker miğferi giymiş Churchill'e benzetilmeye çalışılan bir erkeği tutuğu resmedilmektedir. Bebeğin sol elinde üstünde iri burunlu ve dudaklı insan silueti bulunan bir balon bağlı bulunmaktadır. Roosevelt'e benzetilmeye çalışılan erkeğin sol kolunun üzerinde altıgen yıldız yer almakta, diğer yandan sol elinde baston, sağ elinde de Whisky Old yazan bir biberon taşımaktadır. Dergi kapağında "Der" wird das Kind nicht schaukeln! (“O”, çocuğu sallamayacak!) yazısı bulunmaktadır.

Resim 10. Bebek konulu dergi kapağı

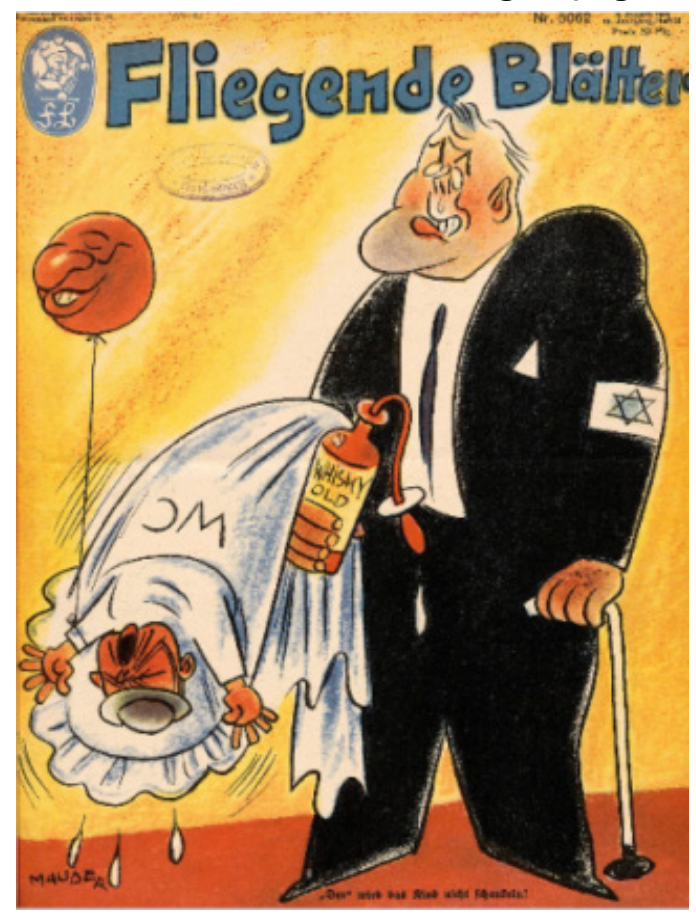

Kaynak: (Blätter, Heidelberg historic literature - digitized, 1942)

Dergi kapağı yan anlam boyutunda ele alındığında Yahudi diasporasının, Roosevelt ve Churchill’i etkilediği algısının meydana getirilmeye çalışıldığı anlaşılmaktadır. Roosevelt, ABD'yi; Churchill, Ingiltere'yi ve altıgen yıldız, Yahudiliği simgelemektedir. Başında İngiliz asker miğferi olması ve üzerinde Winston Churchill'in (WC) baş harflerinin bulunmasıyla, Roosevelt temsilinin elinde tuttuğu erkeğin, Churchill 
temsili olduğu mesajı verilmektedir. Roosevelt temsilinin elindeki biberonun üzerinde Whisky Old yazması Churchill'in içki bağımlısı bir kişi olarak algılanmasına yol açmaktadır. Churchill temsilini tutan kişinin Roosevelt temsili olduğu ise erkeğin baston taşımasıyla ortaya konulmaya çalışılmıştır. Bu açıdan baston, Roosevelt'in metonimi olarak kullanılmıştır. Roosevelt temsilinin sol kolunun üzerinde altıgen yıldızın bulunması, dergi kapağında Roosevelt'in Yahudi olarak sunulduğuna yönelik algının oluşmasına yol açmaktadır. Nitekim Nazi Almanya'sında Yahudileri diğer insanlardan ayırt etmek için Yahudilerin kollarında altıgen yıldız taşımaları istenmiştir. Diğer yandan Churchill temsilinin elindeki balonun iri burunlu ve iri dudaklı sunulmasıyla Yahudi diasporası ile Ingiltere de ilişkilendirilmektedir. Dergi kapağında Yahudi diasporası, bağlılık metaforu olarak kullanılmıştır. Bu şekilde "Yahudi diasporası, ABD ve İngiltere yönetimleri üzerinde etkilidir" miti inşa edilmeye çalışılmaktadır. İnşa edilen bu propaganda mitinde de Yahudi diasporasının ABD yönetimini kontrol altına aldığı iddia edilmektedir.

Tablo 8. Bebek konulu dergi kapağı

\begin{tabular}{|c|c|}
\hline Düz Anlam & Bir erkek ve bebek kıyafetleri içerisindeki başka bir erkek \\
\hline Yan Anlam & Yahudi diasporası, Roosevelt ve Churchill'i etkilediği iddiası \\
\hline Metafor & Yahudi diasporası, bağlıık metaforu olarak kullanılmıştır \\
\hline Metonimi & Baston, Roosevelt'in metonimi olarak kullanılmıştır \\
\hline Simge & $\begin{array}{c}\text { Roosevelt, ABD’yi; Churchill, İngiltere'yi ve altıgen yıldız, Yahudili- } \\
\text { ği simgelemektedir }\end{array}$ \\
\hline Mit & $\begin{array}{c}\text { "Yahudi diasporası, ABD ve İngiltere yönetimleri üzerinde etkili- } \\
\text { dir" miti inşa edilmeye çalışılmaktadır }\end{array}$ \\
\hline
\end{tabular}

\subsection{Savaş Konulu Dergi Kapağı}

Savaş konulu dergi kapağı, Leo Kainradl tarafından hazırlanmıştır. Düz anlam boyutunda incelendiğinde dergi kapağında iki erkeğin el sıkıştığı resmedilmektedir. Sol taraftaki erkeğin başında ABD bayrağı şeklinde bir şapka yer almaktadır. Sol taraftaki erkeğin elinde Verpfändung (Ipotek) yazan, sağ taraftaki erkeğin elinde ise Lieferung (sevkiyat) yazan bir kağıt bulunmaktadır. Diğer yandan sol taraftaki erkeğin yanında dolar, sağ taraftaki erkeğin yanında da sterlin işareti yer almaktadır. Her iki erkeğin ortasında ise altıgen yıldız bulunmaktadır. Dergi kapağında Schöne Seelen (Güzel Ruhlar) yer almaktadır. Sol taraftaki erkeğin Wir führen nur Krieg für die Ideale der Menschheit! (Biz sadece insanlığın idealleri için savaşıyoruz!), sağ taraftaki erkeğin de und für die armen ausgebeuteten Völker (ve yoksul sömürülen halklar için) dediği aktarılmaktadır. 
Resim 11. Savaş konulu dergi kapağı

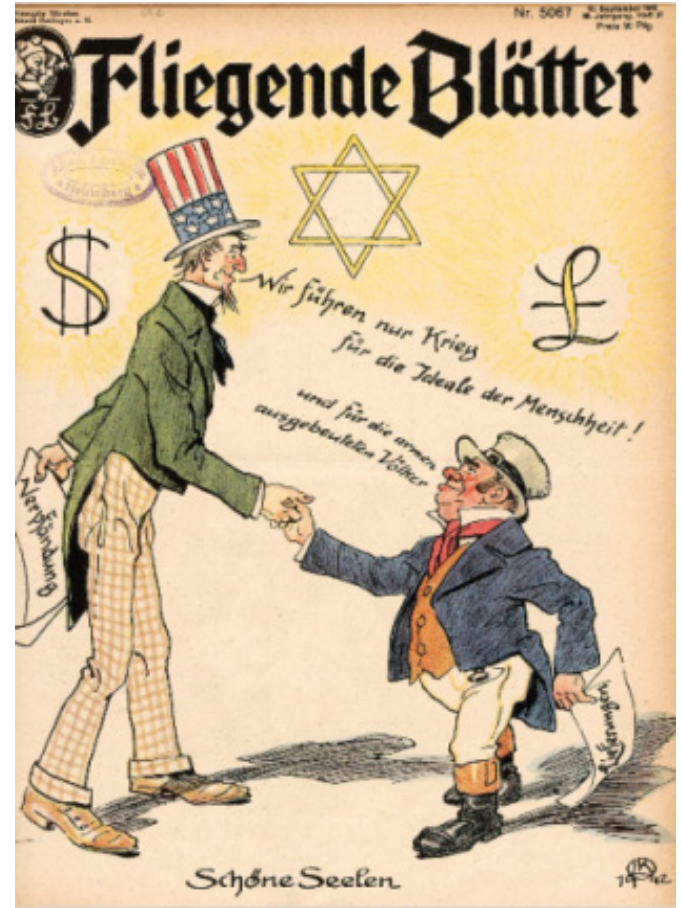

Kaynak: (Blätter, Heidelberg historic literature - digitized, 1942)

Dergi kapağı yan anlam üzerinden incelendiğinde $A B D$ ve İngiltere'nin Nazi Almanya'sına karşı savaşının sözde Yahudilerin çıkarlarını korumak için gerçekleştiği algısı oluşturulmaya çalışılmaktadır. Dolar işareti, ABD'yi; sterlin işareti İngiltere'yi ve altıgen yıldız, Yahudiliği simgelemektedir. El sıkışan erkekler, ABD ve ingiltere halklarının metonimi olarak kullanılmıştır. Dergi kapağında görsel ve yazılı kodlar üzerinden ironi yapılmaya çalışıımıştır. $A B D$ ve İngiltere yönetimlerini temsil eden erkekler, insanlığın idealleri ve yoksul sömürülen halklar için savaştıklarını belirtmiştir. Buna karşılık görsel kodlarda ise ipotek ve sevkiyat yazılı kağıtlardan ve dolar ve sterlin işaretlerinden savaşın ekonomik çıkarlar için sürdürüldüğüne yönelik algı oluşturulmaya çalışılmıştır. Her iki erkeğin ortasında da altıgen yıldızın bulunması, Yahudilerin ekonomik hayata egemen olduğu düşüncesini meydana getirmektedir. Dergi kapağında Yahudi diasporası, egemenlik metaforu olarak kullanılmıştır. Bu şekilde "Yahudi diasporası, ABD ve İngiltere ekonomileri üzerinde etkilidir" miti inşa edilmeye çalışıımaktadır. Bu dergi kapağında doğrudan Yahudi diasporasının sözde $A B D$ ve İngiltere ekonomileri üzerindeki etkisi ortaya konulmaktadır. Böylece savaşın sürdürülmesinin temelinde sözde Yahudilerin ekonomik çıkarları olduğu iddia edilmektedir.

Resim 9. Savaş konulu dergi kapağı

\begin{tabular}{|c|c|}
\hline Düz Anlam & El sıkışan iki erkek \\
\hline Yan Anlam & Savaşın Yahudilerin çıkarlarını korumak için olduğu iddiası \\
\hline Metafor & Yahudi diasporası, egemenlik metaforu olarak kullanılmıştır \\
\hline Metonimi & $\begin{array}{c}\text { El sıkışan erkekler, ABD ve İngiltere halklarının metonimi olarak } \\
\text { kullanılmıştır }\end{array}$ \\
\hline Simge & $\begin{array}{c}\text { Dolar işareti, ABD’yi; sterlin işareti İngiltere'yi ve altıgen yıldız, } \\
\text { Yahudiliği simgelemektedir }\end{array}$ \\
\hline Mit & $\begin{array}{c}\text { "Yahudi diasporası, ABD ve İngiltere ekonomileri üzerinde etkili- } \\
\text { dir” miti inşa edilmeye çalışılmaktadır }\end{array}$ \\
\hline
\end{tabular}




\subsection{Araba Konulu Dergi Kapağı}

Araba konulu dergi kapağı, Helmuth Huth tarafından hazırlanmıștır. Düz anlam açısından ele alındığında dergi kapağında bir arabanın yanında biri Roosevelt'e diğeri Churchill'e benzetilmeye çalışılan iki erkeğin bulunduğu görülmektedir. Her iki erkeğin de düşünceli olduğu yansıtılmaktadır. Arabanın üzerinde Britania (Britanya) ve U.S.A. (A.B.D.) yazıları ve iki tane altıgen şekil bulunmaktadır. Arabanın üstündeki kutularda ise Afrika, Sowjethilfe (Sovyet yardımı) ve 2. Front (2. Cephe) yazıları yer almaktadır. Dergi kapağında Na, Franklin, wer zieht uns jetzt unseren Karren aus dem Dreck? (Pekala, Franklin, arabamızı çamurdan kim çekecek şimdi?) yazısı bulunmaktadır.

Resim 12. Araba konulu dergi kapağı

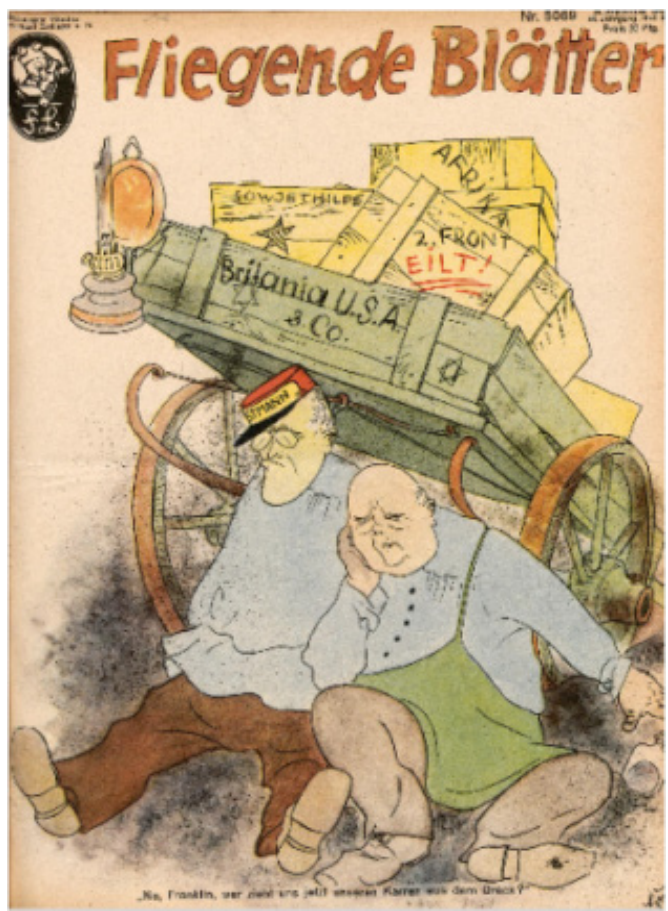

Kaynak: (Blätter, Heidelberg historic literature - digitized, 1942)

Dergi kapağı yan anlam boyutunda ele alındığında Roosevelt ve Churchill'in Yahudilerin çıkarlarını savunduğu algısının oluşturulmaya çalışıldığı anlaşılmaktadır. Arabanın üzerinde yazan Britanya ve A.B.D yazıları, arabanın yanındaki kișilerin Roosevelt ve Churchill olduğu mesajını vermektedir. Roosevelt, ABD'yi; Churchill, İngiltere'yi ve altıgen yıldız, Yahudiliği simgelemektedir. Arabanın üzerinde altıgen yıldızların bulunması, arabadaki malların Yahudilere ait olduğu mesajını vermektedir. Bu açıdan arabadaki kutular, Yahudilere ait malların metonimi olarak kullanılmıştır. Dergi kapağında ABD ve Ingiltere yönetimlerinin Yahudilerin ekonomik çıkarlarına hizmet ettiğine yönelik algı oluşturulmaktadır. Bu aşamada Yahudi diasporası, güç metaforu olarak kullanılmıştır. Dergi kapağında "ABD ve İngiltere yönetimleri, Yahudi diasporası için çalışmaktadır" miti inşa edilmeye çalışılmaktadır. Bu aşamada ABD ve İngiltere'nin Nazi Almanya'sına karşı savaşının sürdürülmesinin nedeni olarak Yahudilerin ekonomik çıkarları olduğu algısı meydana gelmektedir. 
Tablo 10. Araba konulu dergi kapağı

\begin{tabular}{|c|c|}
\hline Düz Anlam & Bir araba ve iki erkek \\
\hline Yan Anlam & Roosevelt ve Churchill'in Yahudilerin çıkarlarını savunduğu iddiası \\
\hline Metafor & Yahudi diasporası, güç metaforu olarak kullanılmıştır \\
\hline Metonimi & $\begin{array}{c}\text { Arabadaki kutular, Yahudilere ait malların metonimi olarak kulla- } \\
\text { nılmıştır }\end{array}$ \\
\hline Simge & $\begin{array}{c}\text { Roosevelt, ABD’yi; Churchill, Ingiltere'yi ve altıgen yıldız, Yahudiliği } \\
\text { simgelemektedir }\end{array}$ \\
\hline Mit & $\begin{array}{c}\text { "ABD ve İngiltere yönetimleri, Yahudi diasporası için } \\
\text { çalışmaktadır” miti inşa edilmeye çalışılmaktadır }\end{array}$ \\
\hline
\end{tabular}

\subsection{Oyuncak Konulu Dergi Kapağı}

Oyuncak konulu dergi kapağı, Josef Mauder tarafından hazırlanmıştır. Düz anlam boyutunda incelendiğinde dergi kapağında siyah kıyafet ve silindir şapka giyen bir erkeğin başı akvaryum şeklinde olan bir oyuncağı taşıdığı resmedilmektedir. Erkeğin üzerindeki kıyafette altıgen bir yıldız bulunmaktadır. Oyuncağın bir elinde baston, diğer elinde çubuğa geçirilmiş üzerinde orak ve çekiç görseli bulunan bir yıldız taşıdığı görülmektedir. Yıldızın bir ucuna iple bir tavşan bağlı bulunmaktadır. Oyuncağın akvaryum şeklindeki başında da Kuzey ve Güney Amerika kıtalarının resimleri yer almaktadır. Diğer yandan oyuncağın başının Roosevelt'e benzetilmeye çalışıldığı anlaşılmaktadır. Dergi kapağında Das Judenspielzeug - oder die Puppe mit dem politischen Wasserkopf (Yahudi oyuncağı - ya da politik su kafalı oyuncak bebek) yazısı bulunmaktadır.

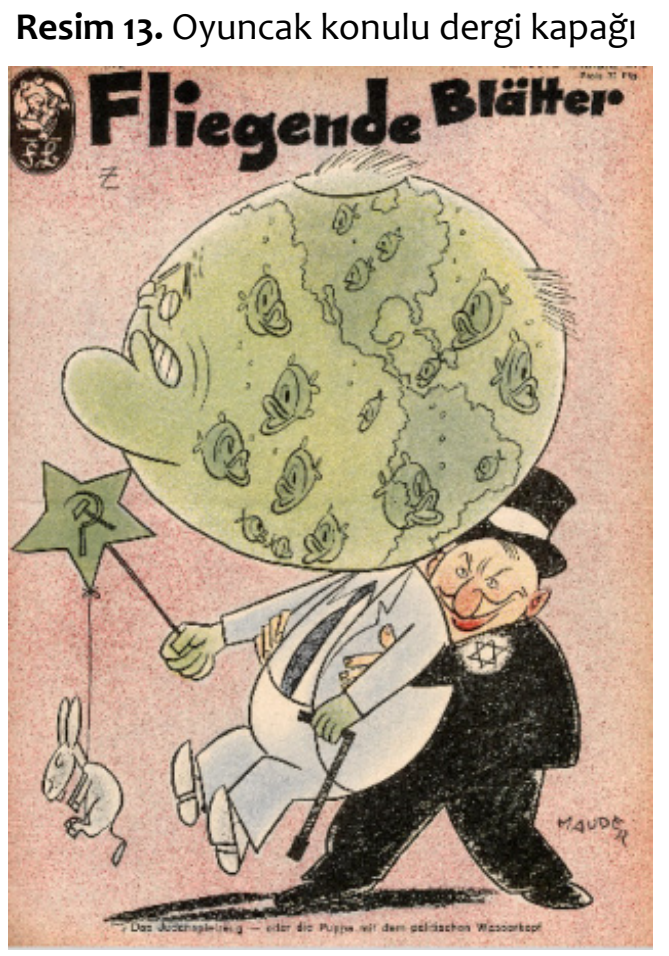

Kaynak: (Blätter, Heidelberg historic literature - digitized, 1942)

Dergi kapağı yan anlam üzerinden incelendiğinde Roosevelt'in Yahudilerin kontrolünde hareket ettiği algısı oluşturulmaya çalışılmıştır. Roosevelt'e benzetilen oyuncağın elindeki baston Roosevelt'in metonimi olarak ön plana çıkmaktadır. Roosevelt'e benzetilen oyuncak, ABD'yi; orak ve çekiç Komünizm ideolojisini ve 
altıgen yıldız, Yahudiliği simgelemektedir. Siyah kıyafet ve silindir şapka giyen erkeğin üzerindeki altıgen yıldız, onun Yahudi olduğu mesajını vermektedir. Bu açıdan Roosevelt'e benzetilen oyuncağı taşıyan erkek, Yahudilerin metonimi olarak sunulmaktadır. Yahudi temsilinin, Roosevelt'e benzetilen oyuncağı taşımasıyla, "Yahudi diasporası, $A B D$ yönetimini kontrol etmektedir" miti inşa edilmeye çalışılmaktadır. Böylece Yahudi diasporası, yönetim metaforu olarak kullanılmıştır. Roosevelt'e benzetilen oyuncağın elinde, çubuğa geçirilmiş üstünde orak ve çekiç bulunan bir yıldız tutmasıyla Yahudi diasporası ve Komünizm ideolojisi ilişkilendirilmektedir. Bu aşamada $A B D$ yönetiminin Yahudilerin çıkarlarına hizmet ettiğine yönelik algı oluşturulmaktadır.

Tablo 11. Oyuncak konulu dergi kapağı

\begin{tabular}{|c|c|}
\hline Düz Anlam & $\begin{array}{c}\text { Bir erkek ve insan görünümlü kafası devasa boyuttaki bir } \\
\text { oyuncak }\end{array}$ \\
\hline Yan Anlam & Roosevelt'in Yahudilerin kontrolünde hareket ettiği iddiası \\
\hline Metafor & Yahudi diasporası, yönetim metaforu olarak kullanılmıştır \\
\hline Metonimi & $\begin{array}{l}\text { Roosevelt'e benzetilen oyuncağı taşıyan erkek, Yahudilerin } \\
\text { metonimi taşımaktadır }\end{array}$ \\
\hline Simge & $\begin{array}{l}\text { Roosevelt'e benzetilen oyuncak, ABD'yi; orak ve çekiç Komü- } \\
\text { nizm ideolojisini ve altıgen yıldız, Yahudiliği simgelemektedir }\end{array}$ \\
\hline Mit & $\begin{array}{c}\text { "Yahudi diasporası, ABD yönetimini kontrol etmektedir" miti } \\
\text { inşa edilmeye çalışılmaktadır }\end{array}$ \\
\hline
\end{tabular}

\subsection{Film Konulu Dergi Kapağı}

Film konulu dergi kapağı, Rolf Peter Bauer tarafından hazırlanmıştır. Düz anlam açısından ele alındığında dergi kapağında bir erkek ve bir kadının bir film setinde olduğu anlaşılmaktadır. Kameranın yanında durması ve üzerindeki görsel kodlar, erkeğin yönetmen olduğuna yönelik mesaj vermektedir. Kadının üzerinde ABD bayrağı şeklinde bir kıyafet bulunmaktadır. Kıyafetin üzerinde de dolar işareti yer almaktadır. Kadının sol elinde zeytin dalına benzer bir dal resmedilmektedir. Kadının ağladığı ve üzgün olduğu yansıtılmaktadır. Erkeğin kameranın yanında elleriyle kadını yönlendirdiği anlaşılmaktadır. Dergi kapağında Ja, Gott der Gerechte! Was mache Se denn für ä Gesicht, Miß LISA? Mer drehe doch ä Sieges-Film! (Evet, Adaletli Tanrı! Yüzünüz nedir Bayan LISA? Bir zafer filmi çekelim!) yazısı bulunmaktadır. 
Resim 14. Film konulu dergi kapağı

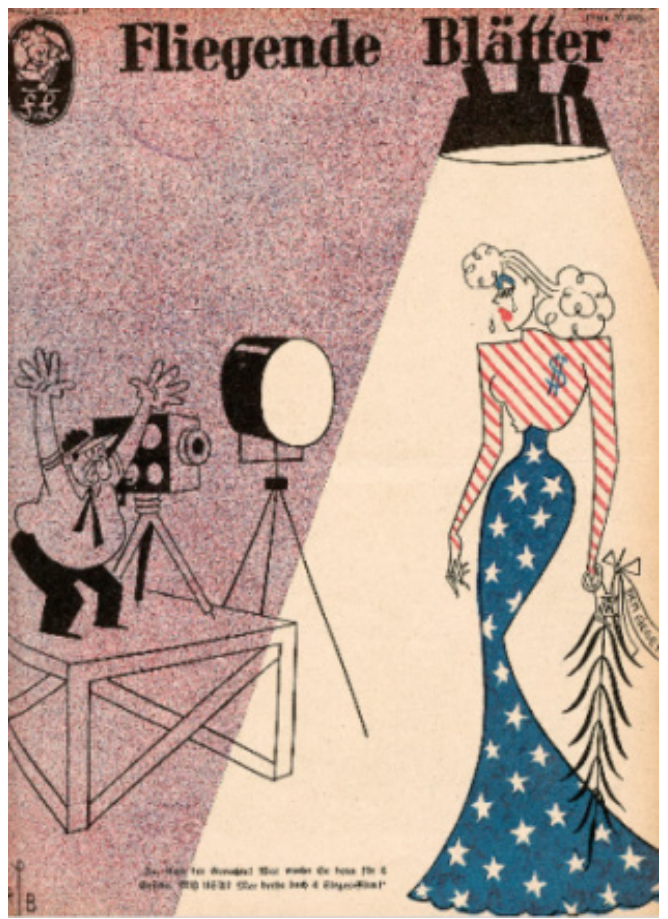

Kaynak: (Blätter, Heidelberg historic literature - digitized, 1942)

Dergi kapağı yan anlam boyutunda ele alındığında ABD kamuoyunun Yahudilerin etkisi altında olduğu algısının meydana getirilmeye çalışıldığı anlaşılmaktadır. ABD bayrağı, ABD halkını; dolar, Kapitalizm'i ve zeytin dalı barışı simgelemektedir. İri burunlu erkek, Yahudilerin metonimi olarak kullanılmıştır. ABD bayrağı şeklinde elbise giyen kadın, ABD kamuoyunu temsil etmektedir. Kadının ağlaması, ABD kamuoyunun savaşı sürdürmek istemediğine yönelik algının oluşmasına yol açmaktadır. Diğer yandan Yahudi temsilinin, kadını yönlendirmeye çalışması, Yahudi diasporasının ABD kamuoyunun savaşı sürdürmesini istediği düşüncesini meydana getirmektedir. Dergi kapağında Yahudi diasporası, kontrol metaforu olarak kullanılmıştır. Bu aşamada "Yahudi diasporası, ABD kamuoyunu şekillendirmektedir" miti inşa edilmeye çalışılmaktadır. Dergi kapağında sözde ABD kamuoyunun Nazi Almanya'sıyla savaşı sürdürmek istememesine karşılık Yahudi diasporası nedeniyle savaşın sürdürüldüğü algısı oluşturulmaktadır.

Tablo 12. Film konulu dergi kapağı

\begin{tabular}{|c|c|}
\hline Düz Anlam & Yönetmen ve kadın \\
\hline Yan Anlam & ABD kamuoyunun Yahudilerin etkisi altında olduğu iddiası \\
\hline Metafor & Yahudi diasporası, kontrol metaforu olarak kullanılmıştır \\
\hline Metonimi & İri burunlu erkek, Yahudilerin metonimi olarak kullanılmıştır. \\
\hline Simge & $\begin{array}{l}\text { ABD bayrağı, ABD halkını; dolar, Kapitalizm’i ve zeytin dalı } \\
\text { barışı simgelemektedir }\end{array}$ \\
\hline Mit & $\begin{array}{c}\text { "Yahudi diasporası, ABD kamuoyunu şekillendirmektedir" } \\
\text { miti inşa edilmeye çalışılmaktadır }\end{array}$ \\
\hline
\end{tabular}




\section{Sonuç}

Makale çalıșması kapsamında incelenen dergi kapaklarında Nazi propagandasının doğrudan ABD'nin Nazi Almanya'sıyla savaşmasının nedeni olarak Yahudi diasporasını ön plana çıkardığı ortaya çıkmışırı. Fliegende Blätter dergisinde savaşın nedeni olarak Yahudi diasporasının suçlanmasıyla Hitler'in 11 Aralık 1941 tarihinde ABD'ye savaş ilan etmesinin Alman kamuoyunda meșrulaştırılmasına çalıșıldığı ileri sürülebilmektedir. Bu şekilde Nazi Almanya'sının savaşta yaşadığı kayıpların sorumluluğu da Yahudi diasporasına atfedilmiştir. Fliegende Blätter dergisinde Yahudi diasporasının kendi çıkarları doğrultusunda savaşa yol açtıkları propaganda mitiyle Almanya'da Nazi iktidarı döneminde Yahudi karşıtı kamuoyunun güçlenmesine çalışıımıştır.

Fliegende Blätter'ın dergi kapaklarındaki ABD'deki Yahudi diasporasının temsillerinin, Der Stürmer'deki Yahudi temsilleri gibi iri burunlu ve kalın/kaba dudaklı sunuldukları görülmüştür. Diğer yandan derginin, Lustige Blätter ve Kladderadatsch mizah dergilerindeki gibi ABD'deki Yahudi diasporasına yönelik olumsuz söyleme sahip olduğu ortaya çıkmıştır. Fliegende Blätter'ın dergi kapaklarında özellikle Roosevelt hedef alınmış ve Roosevelt'in ABD'deki Yahudi diasporasıyla yakın bir ilişki içerisinde olduğu algısı oluşturulmaya çalışılmıştır. Buna karşılık dergi kapaklarında Roosevelt'in Yahudi olduğuna yönelik doğrudan mesaj verilmemiş, yalnızca bir karikatürde Roosevelt'in sol koluna, altıgen yıldız amblemi takılarak, bu algının oluşabilmesine yol açılmıştır. Dergi kapaklarında Roosevelt daha çok Yahudi diasporasının etkisi altında kalmakla suçlanmıştır. Bu aşamada dergi kapakları üzerinden ABD'yi yöneten asıl gücün demokrasiyle seçilen ABD Başkanı Roosevelt değil, ABD'deki Yahudi lobisi olduğuna yönelik algı oluşmuştur. Dergi kapaklarında "Yahudi diasporası, ABD kamuoyunu şekillendirir", "ABD yönetimi, Yahudi diasporasının kontrolü altındadır" "ABD yönetimi, Yahudi diasporası lehine hareket etmektedir" ve "Yahudi diasporası, ABD kamuoyunu şekillendirmektedir" şeklinde inşa edilmeye çalışılan propaganda mitleri üzerinden de ABD'deki Yahudi diasporasının ülke yönetimini ele geçirdiğine yönelik algının oluşmasına zemin hazırlanmıştır.

Nazilerin iktidar dönemi Almanya'da hakim olan Yahudilerin komünizm ideolojisiyle ilișkilendirilmesine yönelik propaganda miti, dergi kapaklarının bir kısmında da ortaya çıkmıştır. Bu şekilde Komünizm ideolojisiyle Yahudiler özdeşleştirilerek, Nazi Almanya'sındaki Komünizm karşıtı kamuoyunun Yahudilere de karşı cephe almasına çalıșılmıştır. Dergi kapaklarında incelenen görsel ve yazılı kodlar genel olarak değerlendirildiğinde çizimlerde mizahi öğelerin ön plana çıkarılarak ABD'deki Yahudi diasporasının Alman kamuoyunda itibarsızlaştııılmaya çalışıldığı ileri sürülebilmektedir. Çalışmada Nazi propagandasının Fliegende Blätter mizah dergisi özelinde ABD'deki Yahudi diasporasına yönelik söylemleri ortaya konulmaya çalışıımıştır. Gelecek çalışmaların, ABD'deki Yahudi diasporasına yönelik Nazi propagandasındaki söylemleri Lustige Blätter ve Kladderadatsch gibi farklı dergiler üzerinden, mevcut çalışmada elde edilen bulgularla karşılaştırmalı olarak incelenmesinin konunun daha kapsamlı şekilde ortaya konulmasını sağlayacağı düşünülmektedir. 


\section{Son Notlar}

'Posterde Штампа у САД је 97\% у ЈЕВРЕЈСКИМ рукама (ABD'deki basının \% 97'si Yahudilerin elinde) yazısı bulunmaktadır.

2 Poster Die Drahtzieher! (Üst akıllar) başlığını taşımaktadır. Posterdeki Almanca metnin Türkçe çevirisi: “Führer 26 Nisan 1942'de şunları söyledi: “Ingiltere'yi 1914’te Birinci Dünya Savaşı'na sürükleyen gizli güçler Yahudilerdi. O zamanlar bizi zor duruma düşüren ve nihayet bizi, Almanya'nın artık zaferle bayrağını eve taşımaması gerektiği sloganı altında teslim olmaya zorlayan güç, Yahudi'ydi. Yahudiler halkımızda devrimi kışkırttılar ve bizi her türlü direnişten mahrum bıraktılar. Ancak 1939'dan beri Yahudiler, Britanya İmparatorluğu'nu tehlikeli krizine sürüklediler. Yahudiler, bir zamanlar Avrupa'yı yok etmekle tehdit eden Bolşevik enfeksiyonun taşıyıcılarıydı. Ama aynı zamanda plütokrasinin savaş kışkırtıcılarıydılar. Bir Yahudi çemberi Amerika'yı, yalnızca Yahudi-kapitalist bir bakış açısıyla, tüm çıkarlarına karşı savaşa sürükledi. Ve Başkan Roosevelt, kendi yeteneğinin yokluğunda, kıdemli adamları için isimleriyle listelemem gerekmeyen entelektüel desteğe sahip: onlar sadece Yahudiler!" (Collection, 1942).

\section{Kaynakça}

Alexander, M. (2006). The meaning of American Jewish history. Jewish Quarterly Review, 423-432.

Aviv, C. S., and Shneer, D. (2005). New Jews: The end of the Jewish diaspora. NY: New York University Press.

Bar-Kochva, B. (2010). Pseudo hecataeus, 'on the Jews': Legitimizing the Jewish diaspora. California: University of California Press.

Baron, S. (1950). American Jewish history: Problems and methods. Publications of the American Jewish Historical Society, 207-266.

Barthes, R. (2014). Çağdaş söylenler. İstanbul: Metis Yayınevi.

Barthes, R. (2015). Bir deneme bir ders: Eiffel Kulesi ve açılış dersi. İstanbul: Yapı Kredi Yayınları.

Bauer, Y. (2017). American Jewry and the holocaust : The American Jewish joint distribution committee, 1939-1945. Wayne State University Press.

Beinart, P. (2010). The failure of the American Jewish establishment. The New York Review of Books, 10-21.

Bessel, R. (2004). The Nazi capture of power. Journal of Contemporary History, s. 169-188.

Blätter, F. (1942, 6 14). Heidelberg historic literature - digitized. https://digi. ub.uni-heidelberg.de/diglit/fb196/0049/: https://digi.ub.uni-heidelberg.de/ diglit/fb196/0049/image adresinden alındı

Blätter, F. (1942, 84 ). Heidelberg historic literature - digitized. https://digi.ub.uni-heidelberg.de: https://digi.ub.uni-heidelberg.de/diglit/fb196/0113/text_heidicon adresinden alındı

Blätter, F. (1942, 5 23). Heidelberg historic literature - digitized. https://digi. ub.uni-heidelberg.de: https://digi.ub.uni-heidelberg.de/diglit/fb196/0257/image adresinden alındı

Blätter, F. (1942, 4 25). Heidelberg historic literature - digitized. https://digi. ub.uni-heidelberg.de: https://digi.ub.uni-heidelberg.de/diglit/fb196/0369/image adresinden alındı

Blätter, F. (1942, 4 13). Heidelberg historic literature - digitized. https://digi. ub.uni-heidelberg.de:https://digi.ub.uni-heidelberg.de/diglit/fb197/0032/ text_heidicon adresinden alındı

Blätter, F. (1942, 3 22). Heidelberg historic literature - digitized. https://digi. ub.uni-heidelberg.de:https://digi.ub.uni-heidelberg.de/diglit/fb197/0304 adresinden alındı 
Blätter, F. (1942, 5 16). Heidelberg historic literature - digitized. https://digi.ub.uni-heidelberg.de: https://digi.ub.uni-heidelberg.de/diglit/fb197/0240/image adresinden alındı

Blätter, F. (1942, 6 11). Heidelberg historic literature - digitized. https://digi.ub.uni-heidelberg.de: https://digi.ub.uni-heidelberg.de/diglit/fb197/0192/image adresinden alındı

Blätter, F. (1942, 09 10). Heidelberg historic literature - digitized. https://digi.ub.uni-heidelberg.de: https://digi.ub.uni-heidelberg.de/diglit/fb197/0160/image adresinden alındı

Blätter, F. (1942, 08 06). Heidelberg historic literature - digitized. https://digi.ub.uni-heidelberg.de: https://digi.ub.uni-heidelberg.de/diglit/fb197/0080 adresinden alındı

Blätter, F. (1942, 08 06). Heidelberg historic literature - digitized. https://digi.ub.uni-heidelberg.de: https://digi.ub.uni-heidelberg.de/diglit/fb197/0048/image adresinden alındı

Blätter, F. (1942, 07 12). Heidelberg historic literature - digitized. https://digi.ub.uni-heidelberg.de: https://digi.ub.uni-heidelberg.de/diglit/fb197/0048/image adresinden alındı

Butler-Smith, A. (2009). Diaspora nationality vs diaspora nationalism: American Jewish identity and zionism after the Jewish state. Israel Affairs, 159-179.

Chiswick, B., and Huang, J. (2008). The earrings of American Jewish men: Human capital, denomination, and religiosity. Journal of the Scientific Study of Religion, 694709.

Cohen, E. (2009). Particularistic education, endogamy, and educational tourism to homeland: An exploratory multi-dimensional analysis of Jewish diaspora social indicators. Contemporary Jewry, 169-189.

Cohen, N. (1999). Jacob H. Schiff: A study in American Jewish leadership. UPNE.

Collection, U. S. (1942, May 27). Collections. https://www.ushmm.org/: https://collections.ushmm.org/search/catalog/irn13549 adresinden alındı

Collins-Kreiner, N., and Olsen, D. (2004). Selling diaspora-producing and segmenting the Jewish diaspora tourism market. Tourism, Diasporas and Space, 279-290.

Dauber, J. (2006). Comic books, tragic stories: Will Eisner's American Jewish history. AJS Rewiev, 277-304.

DellaPergola, S., Rebhun, U., and Tolts, M. (2005). Contemporary Jewish diaspora in global context: Human development correlates of population trends. Israel Studies, 61-95.

DellaPergola, S. (1980). Patterns of American Jewish fertility. Demography, 261-273.

Dieckhoff, A. (2017). The Jewish diaspora and Israel: Belonging at distance? Nations and Nationalism, 271-288.

Dinnerstein, L. (1987). Uneasy at home: Antisemitism and the American Jewish experience. NY: Columbia University Press.

Duker, A. (1950). Emerging culture patterns in American Jewish life: The psycho-cultural approach to the study of Jewish Life in America. Publications of the American Jewish Historical Society, 351-388.

Edrei, A., and Mendels, R. (2007). A split Jewish Diaspora: Its dramatic consequences. Journal for the Study of the Pseudepigrapha, 91-137.

Ehrlich, M. (2009). Encyclopedia of the Jewish diaspora: Origins, experiences, and culture. NY: ABC-CLIO. 
Elo, M., and Vemuri, S. (2016). Organizing mobility: A case study of Bukharian Jewish Diaspora. Diaspora Studies, 179-193.

Elo, M., and Volovelsky, E. (2017). Jewish diaspora entrepreneurs-the impact of religin on opportunity exploration and exploitation. International Journal of Entrepreneurship and Small Business, 244-269.

Elo, M., Taube , F., and Volovelsky, E. (2019). Migration 'against the tide': Location and Jewish diaspora entrepreneurs. Regional Studies, 95-106.

Evans, N. (2009). A strike for radical justice? Transatlantic shipping and the Jewish diaspora. Jewish Culture and History, 21-38.

Feingold, H. (1982). American Jewish history and American Jewish survival. American Jewish History, 421-431.

Feingold, H. (1983). Midrash on American Jewish history. NY: SUNY Press.

Fejgin, N. (1995). Factors contibuting to the Academic excellence of American Jewish and Asian students. Sociology of Education, 18-30.

Finkelstein, N. H. (2010). American Jewish history: A JPS Guide. NY: Jewish Publication Society.

Fishman, S. B. (1995). A breath of life: Feminism in the American Jewish community. Chicago: UPNE.

Fishman, S. B. (1997). Success in curcuit lies: Philip Roth's recent explorations of American Jewish identity. Jewish Social Studies, 132-155.

Fishman, S. B. (2015). Gender in American Jewish life. A. Dashefsky, and I. Sheskin içinde, In American Jewish Year Book 2014 (s. 91-131). NY: Springer.

Ganin, Z. (1977). The limits of American Jewish political power: The America's retreat from partition, November 1947-March 1948. Jewish Social Studies, 1-36.

Goebbels, J. (2016). Gerçek yüzüyle Komunizm ve teori ve pratikte Bolşevizm. Istanbul: Bilge Karınca yayınları .

Goldschmidt, H. (2000). Crown heights is the center of the World's reterritorializing a Jewish diaspora. Diaspora: A Journal of Transnational Studies, 83-106.

Hagel, P., and Peretz, P. (2005). States and transnational actors: Who's influencing whom? A case study in Jewish Diaspora. Diaspora: A Journal of Transnational Studies, 83-106.

Hartman, H. (2016). Gender differences in American Jewish identity: Testing the power control theory explanation. Review of Religious Research, 407-431.

Heilman, S. C. (2006). Sliding to the right: The contest for the future of American Jewish orthodoxy. California: University of California Press.

Himmelfarb, H. S. (1980). The study of American Jewish identification: How it is defined, measured, obtained,sustained and lost. Journal of the Scientific Study of Religion, 48-60.

Horn, G.-R. (1997). International labor and working-class history. Cambridge: Cambridge University Press.

Hyman, P. E. (2003). The normalization of American Jewish history. American Jewish History, 353-359.

Jacobs, B. M. (2005). What's wrong with the history of the American Jewish education? Journal of Jewish Education, 33-51.

Jovanovich, N. (1972). Antimasonska i antikomunistichka izlojba u Belgradu 1941. godine. V. G. Jovan Maryanovich içinde, NOR i revolutsiya u Sırbiyi 1941-1945 (s. 365). Belgrad: Serbia. 
Kahn, A. F. (2014). Transnational traditions: New perspectives on American Jewish history. NY: Wayne State University Press.

Katz, E. A. (2015). Bringing zion home: Israel in American Jewish culture 1948-1967. NY: SUNY Press.

Kaufman, D. (2015). Shul with the pool: The 'Synagogue Center' in American Jewish history. NY: SUNY Press.

Kauvar, E. M. (1993). Introduction: Some reflections on contemporary American Jewish culture. Contemporary Literature, 337-357.

Khanin, V. (2002). The new Russian Jewish diaspora and 'Russian' party politics in Israel. Nationalism and Ethnic Politics, 37-60.

Kosmin, B., and Keysar, A. (2013). American Jewish secularism: Jewish life beyond the synagogue. A. Dashefsky, and I. Sheskin, In American Jewish Year Book 2012 (s. 3-54). Dordrecht: Springer.

Krasner, J. (2012). The Benderly boys and American Jewish education. Chicago: University Press of New England (UPNE).

Krasner, J. (2013). The place of Tikkun Olam in American Jewish life. Jewish Political Studies Review, 59-98.

Lazerwitz, B., Winter, J., Dashefsky, A., and Tabory, E. (1998). Jewish choices: American Jewish denominationalism. NY: SUNY Press.

Lederhendler , E. (2014). The interrupted chain : Traditional receiver countries, migration regimes, and the East European Jewish diaspora, 1918-1939. East European Jewish Affairs, 171-186.

Levantovskaya, M. (2012). The Russian-speaking Jewish diaspora in translation; Liudmila Ulitskaia's Daniel Stein. Slavic Review, 91-107.

Levine, P. (1993). Ellis Island to ebbets field: Sport and the American Jewish experience. Oxford: Oxford University Press.

Liebman, C. (1965). Orthodoxy in American Jewish life. American Jewish Year Book, 21-97.

Loeffler, J. (2015). Nationalism without a nation?: On the invisibity of American Jewish politics. Jewsih Quarterly Review, 3-99.

Marcus, J. (1958). The periodization of American Jewish history. Publications of the American Jewish Historical Society, 125-133.

Markowitz, F. (1995). Criss-crossing identities: The Russian Jewish diaspora and the Jewish diaspora in Russia. Diaspora: A Journal of Transnational Studies, 201-210.

McNab, C. (2015). Hitler'in ordusu, Nazi savaş makinesinin tarihi, 1939-1945. İstanbul: Timaş Yayınları.

Mendelsohn, A. (2007). Tongue ties: The emergence of the Anglophone Jewish diaspora in the mid-nineteenth century. American Jewish History, 177-209.

Michels, T. (2000). Socialism and the writing of American Jewish dream in Miami and LA. American Jewish History, 521-546.

Moore, D. (2009). American Jewish identity politics. Michigan: University of Michigan Press.

Museum, U. H. (1993, 1 1). Special collections. http://www.ushmm.org: https://collections.ushmm.org/search/?f\%5Bclassification_plus_all\%5D\%5B\%5D=Posters adresinden alındı

Nenezić, Z. D. (1987). Masoni u Jugoslaviji (1764-1980). Beograd: Dopunjeno Izdanje.

Porat, R. (2018). The Ausraelis: Israelis in Australia as a test case of distinctiveness visa-vis the Jewish diaspora. Israel Affairs, 167-190. 
Power, S. (2012). Yiddish theatre actresses and American Jewish identity. Shofar, 84-107.

Prell, R. (2000). Developmental Judaism: Challenging the study of American Jewish identity in the social sciences. Contemporary Jewry, 33-54.

Rajak, T. (2018). Jewish diaspora in Greco-Roman antiquity. Interpretation, 146-162.

Ray, J. (2008). New approaches to the Jewish diaspora: The Sephardim as a sub-ethnic group. Jewish Social Studies, 10-31.

Robinson, I. (1994). The invention of American Jewsih history. American Jewish History, 309-320.

Roshwald, A. (1998). Betweencatastrophe and redemption. The European Jewish diaspora and zionism in the twentieth Century. European History Quarterly., 527-537.

Rubin-Dorsky, J. (2001). Philip Roth and American Jewish identity: The question of authenticity. American Literary History, 79-107.

Safran, W. (2005). The Jewish diaspora in a comparative and theoritical perspective. Isael Studies, 36-60.

Sarna, J. (1998b). The cult of synthesis in American Jewish culture. Jewish Social Studies, 52-79.

Sarna, J. D. (1990). American Jewish history. Modern Judaism, 343-365.

Sarna, J. D. (1998a). American Jewish education in historical perspective. Journal of Jewish Education, 8-21.

Schwartz, S. (2007). The Rabbi's wife: The rebbetzin in American life,. NY: NYU Press.

Shanes, J. (1998). Yiddish and Jewish diaspora nationalism. Monatshefte, 178-188.

Shapiro, E. (2005). We are many: Reflections on Amerian Jewish history and identity. Syracuse: Syracuse University Press.

Sheffer, G. (2002). A nation and its diaspora: A re-examination of Israeli-Jewish diaspora relations. Diaspora: A Journal of Transnational Studies, 331-358.

Sheffer, G. (2005). Is the Jewish diaspora unique? Reflections on the diaspora's current situation. Israel Studies, 1-35.

Sheramy, R. (2003). Resistance and war: The Holocaust in American Jewish education, 1945-1960. American Jewish History, 287-313.

Sığırcı, i. (2016). Göstergebilim uygulamaları, metinleri, görselleri ve olayları okuma. Ankara: Seçkin Yayıncılık.

Singerman, R. (1984). The American Jewish press, 1823-1983; A bibliographic survey of research and studies. American Jewish History, 422-444.

Smith, R. (1998). Anti-semitism and Nazism: Reconciling Fromm and Godhagen. American Behavioral Scientist, 1324-1362.

Stein, S. (2011). Protected persons? The Bagdadi Jewish Diaspora the British State, and the persistence of empire. The American Historical Review, 80-108.

Stojanović, A. (2015). The 1941 anti-masonic exhibition in Belgrade in the context of Nazi anti-masonic activities in occupied Europe, 1939-1945 . Vojnoistorijski glasnik 1: 93, 93-122.

Strauss, L. (2011). Staying afloat in the melting pot: Constructing an American Jewish identity in the Menorah Journal of the 1920s. American Jewish History., 315-331. 
Sulzberger, A. H. (1941, 10 22). Grand anti-masonic exhibition. https://collections.ushmm.org: https://collections.ushmm.org/search/catalog/irn542645 adresinden alındı

Tcherikover, V. (1963). The decline of the Jewish diaspora in Egypt in the Roman period. Journal of Jewsih Studies., 1-32.

Times, N. (t.y.). https://collections.ushmm.org/search/catalog/irn 542645 adresinden alındı

Toll, W. (1997). Horace M. Kallen: Pluralism and American Jewish identity. American Jewish Studies, 57-74.

Urofsky, M. (1981). American Jewish leadership. American Jewish History, 401-419.

Vieira, N. (2001). Editor's introduction: The Jewish diaspora of Latin America. Shofar: An Interdisciplinary Journal of Jewish Studies, 1-5.

Vital, D. (1994). Israel and the Jewish diaspora: Five comments on the political relationship. Israel Affairs, 171-187.

Voigtlander, N., and Voth, H. J. (2012). Persecution perpetuated: The medieval origins of anti-semitic violence in Nazi Germany. The Quarterly Journal of Economics, 1339-1392.

Waxman, D. (2018). Trouble in the tribe: The American Jewish conflict over Israel. Princeton: Princeton University Press.

Wink, A. (1987). The Jewish diaspora in India: Eighth to thirteeth centuries. The Indian Economic \& Social History Review, 349-366.

Zelekha, Y., Sharabi, E., and Bar-Efrat, Q. (2012). Trade, institutions and religion: The effect of the Jewish Diaspora on Israel's foreign trade. Applied Economics Quarterly, 111-137.

Zipperstein, S. J. (1997). Commentary and the American Jewish culture in the 1940 s and 1950s. Jewish Social Studies, 18-28. 


\title{
MEDIAD \\ Medya ve Din Araștırmaları Dergisi | Journal of Media and Religion Studies \\ Jews in the US in the Nazi Press: \\ Review on the Fliegende Blätter Humor Magazine
}

\author{
Elif Hatun KILIÇBEYLi
}

\section{Extended Abstract}

'Political communication', caused by the composition of political history, one of the sub-fields of study that make up the discipline of international relations, with Sociology, the roof of Other Social Sciences, consists of different tools that have the characteristics of integrating or separating societies. After the National Socialist German Workers'Party (NSDAP), which came to power as a result of the general elections held in Germany on March 5, 1933, gained power, anti-semitic rhetoric began to find an intense place in the German press. The Nazis began to dominate the political and social life in the country after the NSDAP came to power in Germany. With the death of President Paul von Hindenburg on August 2, 1934, Hitler succeeded in gaining absolute control in the country by assuming both the presidency and the prime ministry duties with the title of Führer (leader). The fact that the Nazis were the only power in Germany caused the country to be referred to as Nazi Germany and to carry out intense propaganda aiming to dominate the country's own thoughts and ideologies. On the other hand, Nazi propaganda turned towards the construction of enemies against Jews in German society and portrayed Jews as a major threat to German society and humanity. It was claimed that the Jewish diaspora in Germany exposed the German people to economic exploitation. Apart from the Jewish diaspora in Germany, the anti-Semitic Nazi propaganda also targeted the Jewish diaspora in the USA and claimed that the Jews took control of the US administration. Especially in humor magazines, the claims that US President Franklin D. Roosevelt was under the control of the Jews were conveyed to the masses with humorous language. During this period, one of the humor magazines targeting the Jewish diaspora in the USA was Fliegende Blätter.

In the study, it was tried to shed light on the propaganda activities carried out by the Nazis against the Jewish diaspora in the USA over the Fliegende Blätter humor magazine. At this stage, it was aimed to reveal what visual and written messages Nazi propaganda gave against the Jewish diaspora in the USA, how it presented the Jews, and what propaganda myths it tried to construct about the Jews. Thus, it was tried to answer the question "How was the Jewish diaspora in the USA presented in Nazi propaganda?" within the scope of the study. The findings obtained in the study are important in terms of providing information about the Nazi propaganda against the Jewish diaspora in the USA and shedding light on the use of humor for propaganda purposes.

It was revealed that Nazi propaganda directly brought the Jewish diaspora to the fore as the reason why the USA was fighting Nazi Germany on the covers of the magazine examined within the scope of the study. It can be claimed in Fliegende Blätter magazine that Hitler's war declaration against the USA in 1941 was tried to be legitimized by the German public by accusing the Jewish diaspora as the ca- 
use of the war. In this way, the responsibility for the losses suffered by Nazi Germany in the war was also attributed to the Jewish diaspora. It was tried to strengthen the anti-Jewish public opinion in Nazi Germany with the propaganda myth that the Jewish diaspora caused a war in their own interests over Fliegende Blätter magazine.

Representations of the Jewish diaspora in the US on Fliegende Blätter's magazine covers were presented with big noses and lips, as the Jewish representations in Der Stürmer. On the other hand, it was revealed that the magazine had negative discourse towards the Jewish diaspora in the USA, as in the Lustige Blätter and Kladderadatsch humor magazines. Roosevelt was particularly targeted on Fliegende Blätter's magazine covers and it was attempted to form a perception that Roosevelt had a close relationship with the Jewish diaspora in the USA. On the other hand, a direct message was not given on the covers of the magazine that Roosevelt was a Jew, only a hexagonal star emblem was attached to Roosevelt's left arm in a cartoon, which could lead to this perception. On the covers of the magazine, Roosevelt was mostly accused of being under the influence of the Jewish diaspora. At this stage, a perception emerged that the real power governing the USA through magazine covers was not the US president Roosevelt, who was elected with democracy, but the Jewish lobby in the USA. On the covers of the magazine, there may be a perception that the Jewish diaspora in the USA took over the country through the propaganda myths "The Jewish diaspora shapes the US public opinion", "The US administration is under the control of the Jewish diaspora" "The US administration acts in favor of the Jewish diaspora" and "The Jewish diaspora shapes the US public opinion". When the visual and written codes examined on magazine covers are evaluated in general, it can be claimed that the Jewish diaspora in the USA is tried to be discredited in Germany by bringing the humorous elements to the fore in the drawings.

Araştırmacıların Katkı Oranı Beyanı / Contribution of Authors

Araştırma tek bir yazar tarafından yürütülmüştür.

The research was conducted by a single author.

$* * * * * * * *$

Çıkar Çatışması Beyanı / Conflict of Interest

Çalışma kapsamında herhangi bir kurum veya kişi ile çıkar çatışması bulunmamaktadır.

There is no conflict of interest with any institution or person within the scope of the study.

$* * * * * * * *$

Intihal Politikası Beyanı / Plagiarism Policy

Bu makale iThenticate yazılımılla taranmıştır. İntihal tespit edilmemiştir.

This article has been scanned by iThenticate. No plagiarism was detected.

$* * * * * * * *$

Bilimsel Araştırma ve Yayın Etiği Beyanı / Scientific Research and Publication Ethics Statement

Bu çalışmada "Yükseköğretim Kurumları Bilimsel Araştırma ve Yayın Etiği Yönergesi” kapsamındaki kurallara uyulmuştur.

In this study, the rules stated in the "Higher Education Institutions Scientific Research and Publication Ethics Directive" were followed. 